\title{
The Euro Is Good After All: Corporate Evidence*
}

\author{
Arturo Bris \\ Yrjö Koskinen \\ Yale School of Management \\ Stockholm School of Economics \\ Mattias Nilsson \\ Stockholm Institute for Financial Research
}

SSE/EFI Working Paper No. 510

August 2002

${ }^{*}$ We thank Malcolm Baker, Judy Chevalier, Mariassunta Giannetti, Massimo Massa, Geert Rouwenhorst, Bernard Yeung, and audiences at Stockholm School of Economics, Bank of Finland, NYU Salomon Center Conference on the Euro, the CEPR Summer Symposium in Gerzensee, Yale School of Management, and the NBER Summer Institute in Cambridge for helpful comments. We also thank Vanessa Janowski and Teresa Kwon for excellent research assistance. Bris is from Yale School of Management, 135 Prospect Street, New Haven, CT 06511-3729 USA. Tel: +1-203-432-5079; e-mail: arturo.bris@yale.edu. Koskinen is from Stockholm School of Economics, P.O.Box 6501, SE-113 83 Stockholm, Sweden. Tel: +46-8-736-9145; e-mail: yrjo.koskinen@hhs.se. Nilsson is from Stockholm Institute for Financial Research, Wallingatan 11, SE-111 60 Stockholm, Sweden. Tel: +46-8-503-206-30; e-mail: mattias.nilsson@sifr.org. This paper was written while Nilsson was visiting the International Center for Finance (ICF) at Yale School of Management. He wishes to thank the ICF for its hospitality during his stay. This article is produced as a part of a CEPR project on Understanding Financial Architecture: Legal Framework, Political Environment and Economic Efficiency, funded by the European Commission under the Human Potential - Research Training Network program (Contract No. HPRN-CT-2000-00064). The authors are responsible for all remaining errors. 


\begin{abstract}
In this paper we study the changes in corporate valuation, investments, and financing choices induced by the formation of Economic and Monetary Union (EMU) in Europe. We use corporate-level data from ten countries that adopted the euro, the three EU countries that did not join EMU, as well as Norway and Switzerland. We show that the introduction of the euro has increased valuations for large firms in EMU countries, especially in countries that had experienced currency crises. Firm values have also increased for firms that were previously exposed to currency risks irrespective of size. Investments have increased for all firms, but the effects are bigger for large firms and for firms coming from countries with experiences of currency depreciations. The increase in investments has been financed mainly via debt issues. The evidence provided here supports the view that the introduction of the euro has lowered firms' cost of capital by eliminating currency risks among the countries that have adopted the common currency, and by further increasing capital market integration in Europe.

KeYwords: Economic and Monetary Union (EMU), the euro, valuation, investment, debt, equity, cost of capital, currency risk.
\end{abstract}

JEL classification: F33, F36, G32 


\section{Introduction}

Economic and Monetary Union (EMU) and the creation of a new common currency for Europe is arguably the most significant institutional change in international financial markets during the past quarter century. The introduction of the euro as a common currency has already changed the functioning of European financial markets significantly, especially by fostering the creation of a corporate bond market comparable to that of the U.S. ${ }^{1}$ Even though most observers agree on the historic significance of the new currency, there has been a lot of scepticism about the wisdom of the endeavour. It is not clear whether EMU has had a positive or negative effect on European corporations. This paper aims to address this issue by looking at corporate valuations, investments, and financing choices of European corporations.

We use corporate level data from ten countries that adopted the euro ${ }^{2}$, the three EU countries (Denmark, Sweden, and the U.K.) that did not join EMU, as well as Norway and Switzerland. Using yearly data we study how the introduction of the euro has affected Tobin's Q, investments and financing choices in panel regressions that span the years from 1995 to 2000. We use the year 1998 as the benchmark for adoption of the euro, instead of the official beginning of EMU in January 1, 1999 for two reasons: in May 1998 the European Council decided on which countries where allowed to join EMU; second, already in January 1998 there was a consensus on which countries would adopt the euro as their currency ${ }^{3}$.

We show that in the period 1998-2000, Tobin's Q for large firms in the Euroland has increased by $7.9 \%$ per year compared to firms in non-EMU countries, after controlling for firm, country, and time specific effects. The increase in valuation is higher for large firms in euro countries with a history of recent currency crises compared to the euro countries that managed to stay within in the European Monetary System during the turmoil of the early 1990s (13.8\% compared to $6.1 \%)$. The previous results suggest that the adoption of the euro has lowered the cost of capital for large European firms through the elimination of intra-European currency risks, especially for large firms coming from countries that were expected to have significant currency risk premia. Furthermore, among small firms, we only document a significant increase in valuation for firms coming from countries which have experienced recent currency crises (an increase of $13.2 \%)$. Again, this result supports the view that cost of capital has declined because of the euro. In sum - the euro has increased the value of these firms that we expect ex ante to benefit the most from the elimination of currency risks: large firms, firms in countries with weak currencies, and firms exposed to currency risks.

Our results are based on a large sample of firms from several different countries. In studies of this kind an easy way of inflating the power of the estimates is to use firm-level rather than country-level data. If 
firms behave similarly within a country, firm-level data is just a replication of country results, but with lots of highly correlated observations, and hence with artificially high t-statistics. We are instead fair to the reader. The significance of our estimates is free of cross-dependencies, since we estimate panel regressions with standard errors that are adjusted for clustering of observations by country and year. This means that, if firms in our sample solely replicate the other firms in the same country, our t-statistics should be close to zero. The power of our results thus comes from the use of many observations - something that is not possible to achieve by using only country-level data-corresponding to firms with different characteristics and controlling for within-country dependencies. Then we remove firm, country, and time effects, and isolate the direct effect of the common currency on firm behavior. The final result is that there is a positive and significant relationship between the common currency and firm value. We also perform robustness checks to show that our main finding also holds after controlling for other currency risks, in particular dollar risks. The result also holds when we exclude Germany and the U.K. from the analysis. These are the countries that dominate the sample.

It is important to note that the decrease in cost of capital is not a necessary consequence of the elimination of currency risks, because by adopting the euro EMU countries have also given up independent monetary policy. Hence, firms in EMU countries cannot rely any longer on changes in monetary or exchange rate policy to help them out if country-specific shocks have occurred. For instance if companies in some EMU countries are more exposed to dollar risks than companies in other EMU countries, the European Central Bank could be more reluctant to change monetary policy in face of adverse dollar shocks than independent central banks would have been. Similarly, if there are asymmetric inflation shocks among EMU countries, some companies could be adversely affected. As a result, some EMU firms could in principle have ended up bearing more risks than before. However, the empirical results do not support this view.

In addition to the elimination of intra-European currency risks, EMU may have increased financial integration in Europe by reducing the investment restrictions that some institutional investors had prior to the adoption of the euro. For example some European pension funds have the restriction that they can not invest more than $20 \%$ of their funds to assets denominated in a foreign currency. Before the common currency was adopted all securities denominated in another European currency were subject to this restriction. Of course this restriction is now void among EMU countries. As a result, the cost of capital may have decreased also through better risk sharing opportunities in Europe.

Another interpretation for the increase in Tobin's Q would be that firms' investment opportunities have improved because of the euro, thus resulting in higher valuations. We do not, however, think that this 
is the correct interpretation, since the single market for Europe that would arguably increase investment opportunities and hence affect Tobin's Q was created a long time before the creation of EMU. ${ }^{4}$ In fact, the creation of the single market resulted in significant increases in intra-European foreign direct investments and mergers (European Economy, 1997), suggesting that investment opportunities were positively affected, but the timing of these events is just not correct for the period we study.

If the cost of capital were lower, then firms would also invest more, so long as investment opportunities had not worsened. We indeed find that the introduction of the euro has had a positive effect on investments for firms in the euro-zone. This effect is stronger for firms that come from EMU countries that used to suffer from currency crises, and for large firms. The next logical question is, how have the investments been financed? It is not obvious how the lower cost of capital should affect debt and equity choices. What we find is that the increase in investments have mainly been financed with debt, but firms that would have benefitted from currency depreciations have also issued more equity.

This study builds on several contributions in corporate and international finance. Danthine et al. (2000) have a comprehensive survey of the relevant issues affecting financial markets after the introduction of the euro. Additionally, Galati and Tsatsaronis (2001) give a good overview of the recent developments in European financial markets fostered by the new currency. In particular, Santos and Tsatsaronis (2002) show that euro has induced a significant reduction of underwriting fees for European corporate bonds.

Adler and Dumas (1983), Solnik (1973), and Stulz (1981) develop international asset pricing models, where assets are priced with respect to their beta with the world market portfolio. This result assumes that there are no restrictions on consumption and investment choices and that the purchasing power parity (PPP) holds. If the PPP does not hold, then currency risks should be priced in capital markets, as shown by Adler and Dumas (1983). Indeed, Dumas and Solnik (1995) show empirically that currency risk is priced, and De Santis and Gerard (1988) show that currency risk has been a significant part of overall systematic risk. Among studies that focus on Europe, Hardouvelis et al. (2001) find that there has been increasing integration in European equity markets towards the end of 1990s. They also show that currency risk has been a significant part of the total risk of equity investing. De Santis et al. (1999) provide evidence that currency risk has been priced in European equity markets. The elimination of currency risks within the euro-zone could then lower the cost of capital in the countries that have joined EMU. Confirming this view, Bartram et al. (2002) show that due to the euro, the market risk has been reduced for those firms that have significant exports to EMU countries implying that the currency risk has been a part of non-diversifiable risk in Europe. Also, Bartram et al. (2002) find that the effect has been stronger for large firms, consistent with our findings. 
Errunza and Losq (1985), and Eun and Janakiramanan (1986), show how partial segmentation of capital markets due to investment restrictions affects asset prices. Investment restrictions lead to a situation in which local risks are priced in capital markets. Moreover, even though formal restrictions in investing abroad have been reduced, there is still the well-known issue of home equity bias, as pointed out by French and Poterba (1991), Cooper and Kaplanis (1994), and Tesar and Werner (1995). ${ }^{5}$ Consistent with the view that there is a home equity bias, Rouwenhorst (1999) finds that even during the 1990s country factors have been more important than industry factors in determining stock returns in Europe. If the adoption of the euro leads to diminishing home equity bias, then cost of capital should decrease in EMU countries because of better risk sharing among investors.

The paper is organized as follows: section II contains the data description, in section III we study the valuation effects of the common currency. In section IV we analyze the change in investments in the countries in our sample. We also study the valuation effect of macroeconomic convergence, as well as the impact of cross-border mergers. Section $\mathrm{V}$ is devoted to the analysis of capital structure choices. We perform robustness checks in section VI, and section VII concludes.

\section{Data Description}

\section{A Sources}

The sample of firms used in this study is gathered from Datastream and covers the period 1995-2000. The sample includes firms from all countries adopting the euro, with the exceptions of Greece and Luxembourg. Greece and Luxembourg are excluded because firms from these countries lack data in Datastream for some variables we use in the empirical analysis. Moreover, Greece joined the euro in June 2000. Thus, our sample includes firms from the following ten countries that have adopted the euro: Austria, Belgium, Finland, France, Germany, Ireland, Italy, the Netherlands, Portugal, and Spain. The sample also include firms from the three remaining EU, non-EMU countries (Denmark, Sweden, and the U.K.) as well as firms from Norway and Switzerland. We consider these five countries to constitute appropriate benchmark countries for an analysis of the impact of the euro on firms' financial decisions.

For our 15 sample countries, we include all firms that have stock market and accounting data available for at least the period 1995-1998. ${ }^{6}$ We impose this requirement because we want to analyze within-firm changes following the introduction of the euro and thus need firms to exist both before and after the introduction of the euro (as mentioned, we consider 1998 to be the effective event-year for the introduction 
of the euro). Our final sample consists of 1,988 firms (11,364 firm-year observations): 884 firms $(5,175$ firm-year observations) from the EMU countries and 1,104 firms (6,189 firm-year observations) from the non-EMU countries (as a comparison, 4,108 firms from the sample countries have data available on the required variables for at least one year during the sample period). Germany contributes the most firms to the EMU sample with 396 firms (2,298 firm-year observations), whereas the U.K. dominates the non-EMU sample with 877 firms (4,844 firm-year observations). However, our results are robust to excluding both of these countries.

\section{B Tobin's Q, Investments, and Leverage Ratios}

Tobin's Q is calculated in the paper as the book value of total assets (Datastream company account item \#392), minus the book value of the common equity (Datastream company account item \#305), plus the market value of the common equity (number of shares outstanding times end-of-year stock price), divided by the book value of total assets. We compute the ratio of investments to total assets as the change in total assets in a given year divided by the past-year total assets. Since we exclude depreciation, ours is a measure of net investments.

To investigate how the investments have been financed, we analyze changes in debt and equity. Debt is measured as the book value of nonequity liabilities. The book value of total nonequity liabilities is calculated by deducting total book value of equity (Datastream company account item \#307) from the book value of total assets (Datastream item \#392). In particular, we calculate issuance ratios for debt and equity by following the method proposed by Baker and Wurgler (2002). That is, we decompose the change in total assets as the change in equity plus the change in debt, in the following way:

$$
\begin{aligned}
\frac{A_{t}-A_{t-1}}{A_{t-1}} & =\frac{\left(D_{t}+E_{t}+R E_{t}\right)-\left(D_{t-1}+E_{t-1}+R E_{t-1}\right)}{A_{t-1}} \\
& =\frac{D_{t}-D_{t-1}}{A_{t-1}}+\frac{E_{t}-E_{t-1}}{A_{t-1}}+\frac{\Delta R E_{t}}{A_{t-1}}
\end{aligned}
$$

where $A, D, E$, and $R E$ denote the firm's assets, debt, equity, and retained earnings, respectively. Changes in retained earnings are measured as profits after tax, minority interest, dividends, extraordinary items, director bonuses and allocations to untaxed reserves (Datastream item \#196). Indirectly, we calculate the firm's net equity issuance activity in a given year as $\frac{E_{t}-E_{t-1}}{A_{t-1}}=\frac{A_{t}-A_{t-1}}{A_{t-1}}-\frac{D_{t}-D_{t-1}}{A_{t-1}}-\frac{\Delta R E_{t}}{A_{t-1}}$, that is, as the change in total assets (the net investments ratio) minus the change in total debt and the change in retained earnings. We interpret $\frac{E_{t}-E_{t-1}}{A_{t-1}}$ as a measure of newly issued equity in period $t$. 


\section{Country and Firm Classifications}

First we classify firms into two groups, depending on whether they are from EMU countries or from other European countries. Next we further group firms within the EMU group, depending on whether the country is a weak EMU member, or a strong EMU member. For our purposes, weak EMU countries are those that suffered a currency crisis in the years before the introduction of the euro. These countries are Finland, Ireland, Italy, Portugal, and Spain. ${ }^{7}$ The other euro countries (Germany, France, Netherlands, Belgium, and Austria) did not suffer significant currency depreciations during the EMS crisis in early 1990s, hence the label "strong EMU countries". An alternative way of classifying countries would be to measure exchange rate uncertainty with the exchange rate volatility in the years before the implementation of the euro. However, we do not deem such a measure appropriate, because different countries had different bands of fluctuation within the system. The classification into weak and strong EMU countries is important, because the previous monetary arrangements in Europe did not manage to provide exchange rate stability for the weak EMU countries and hence the introduction of a common currency would be especially significant for the weak countries. Notice that the labels of weak and strong EMU countries only applies to the weakness and strength of the currencies prior to the EMU, and not to the overall economic performance of the respective countries.

Firms are also classified depending on their size. Within each country, we calculate the median size of the firms in the sample as of December 1995. Then we split the total sample of firms between large and small companies, depending on whether their size is above or below the country median. Bartram et al. (2002) show that large firms have benefitted more from European monetary integration in terms of reduction in market risk. Dahlquist and Robertsson (2001) and Kang and Stulz (1997) also have shown that large firms benefit more from market integration because foreigners tend to invest in large firms.

We also analyze firm performance depending on the firm's exposure to exchange rate movements. We sort companies within a country into three groups by using individual companies' stock market returns. In the first group we have companies whose stock returns significantly decrease when the domestic currency appreciates with respect to the euro (positive-exposure companies), in the second group we place those companies whose stock returns significantly increase (negative-exposure companies), and the third group is for companies that did not have a significant currency exposure. We detail the computation of the exchange rate beta coefficients (ERBs) in Appendix A.

Positive ERBs therefore imply

1. that a firm's assets derive primarily from exports, 
2. that the firm's currency exposure is not hedged by other means - derivatives or foreign financing, or

3. the firm's liabilities are mostly denominated in the domestic currency.

Conversely, a negative ERB is an indication that

1. the firm's exposure to currency risk is not hedged

2. the firm's suppliers are mainly located in another euro-country, or

3. the firm's liabilities are mostly denominated in a foreign currency.

As a result, firms with positive ERBs have their assets (investments) positively exposed to currency depreciations. Similarly, firms with negative ERBs have their liabilities (financing) positively influenced by currency depreciations. Our procedure is a useful simplification and not very demanding in terms of data. An alternative to the stock-based exposure is to have detailed information on each company's balance sheet (foreign sales, foreign liabilities), as well as on hedging practices. Data on hedging practices is currently not available.

Table 1 shows the percentage of firms in each country with either positive or negative ERBs. We also report the median exchange rate beta among all firms in a given country. Only four countries in the EMU area have positive exposure: Germany, France, the Netherlands, and Portugal. Norway and Switzerland have positive exposure as well. On average, $23.7 \%$ of the firms in EMU countries display a significant currency exposure at the $10 \%$ level in double-sided t-tests (or, equivalently, at the $5 \%$ level in one-sided t-tests), and 30\% in the non EMU countries.

\section{[INSERT TABLE 1]}

In the next section we provide descriptive evidence on the differences in firm value among European countries in the time period around the introduction of the euro.

\section{Firm Value and the Euro}

\section{A Main Results}

Table 2 reports the median Tobin's Q of sample firms, for the 15 countries we consider. We classify countries by their EMU membership. The first observation is that, while in the EMU countries Q increases $5.21 \%$ in the period 1995-2000, it falls $11 \%$ in the non-EMU-countries. Among the weak EMU countries, increases in Tobin's Q are 20.41\% in Italy, $14.04 \%$ in Spain, 10.64\% in Finland, $9.40 \%$ in Ireland, and 5\% in Portugal. These are in general higher than in the strong EMU countries: $12.39 \%$ in Belgium, $8.18 \%$ in France, $3.60 \%$ in the Netherlands, $-1.57 \%$ in Germany, and $-4.55 \%$ in Austria. Moreover, while Q increases 
in some non-EMU countries (21.78\% and 6.96\% increases in Switzerland and Sweden, respectively), it decreases in Denmark (-0.86\%), Norway (-9.84\%), and the U.K. (-15.86\%). Firm values in the pre-euro period are significantly larger in the non-EMU area. Basing our results on non-parametric tests, we show in Table 2 that countries in Euroland have higher Tobin's Q in 1998. This suggests a positive valuation effect of the euro. In the post-euro period, we do not find any significant difference between EMU- and non-EMU countries.

\section{[INSERT TABLE 2]}

In order to analyze the effects of the introduction of the euro, we next estimate a fixed effects model. The dependent variable is the Tobin's Q for the firms in the sample. We control for year- and firm-fixed effects. By using firm-specific fixed effects, we simultaneously control for both constant country factors (e.g., taxation, accounting rules, legal environment, and so forth) and for constant firm factors (e.g., industry effects). Furthermore, because we use fixed effects, estimators will be based on the time-series within-firm variation in variables. Thus, since the objective of our study is to investigate whether there is a regime switch in firms' valuations after the introduction of the euro, fixed effects regressions seem particularly suitable. We interact three dummy variables. The first dummy variable, "EMU country", takes the value one for firms in countries in the euro zone, irrespective of the year of the corresponding observations. A "Post-euro dummy variable" equals one for years 1998, 1999, and 2000, and zero otherwise. Finally, we use a dummy for the weak EMU countries.

Our additional controls include the ratio of earnings before interest, taxes, depreciation, and amortization (EBITDA) to total assets, the firm's sales (in logarithms), the ratio of fixed tangible assets to total assets, the domestic stock market return, and the current year real GDP growth. Profitability directly affects a firm's value, and we measure it with the ratio of EBITDA to total assets. We control for firm size with the log of sales. The ratio of fixed tangible assets to total assets proxies agency costs. If a large fraction of the assets are tangible, then the firm is easier to monitor. Moreover, the tangibility of assets also reflects the firm's investment opportunities. Investment opportunities and Tobin's Q are positively related (McConnell and Servaes, 1990). Since an increase in a firm's market value can be driven by market movements, we control for the domestic market return, in euros. Finally, the current year real GDP growth accounts for cross-country differences in the business cycle.

Because we use firm-level data to estimate what essentially amounts to country-level effects, one important concern regards the possibility of dependence between firms within a country for a particular year. If this cross-dependence is not controlled for, the size of the estimated standard errors can be severely 
underestimated. We deal with this problem by calculating robust standard errors that are adjusted for clustering of observations by country and year. In particular we use the following variance-estimator:

$$
V_{\text {CLUSter }}=\left(X^{\prime} X\right)^{-1} \cdot \sum_{j=1}^{N_{c}} u_{j}^{\prime} \cdot u_{j} \cdot\left(X^{\prime} X\right)^{-1},
$$

where

$$
u_{j}=\sum_{j_{\mathrm{cluster}}} e_{i} \cdot x_{i}
$$

and $n_{c}$ is the total number of clusters-the number of country-years in the sample, $X$ is the matrix of explanatory variables, $e_{i}$ is the residual for firm-year observation $i$, and $x_{i}$ is the vector of corresponding values for the explanatory variables.

Since the endogenous variable in our regression is the $\log$ of $\mathrm{Q}$, the interpretation of the coefficients is straightforward and represents the percentage change in Q induced by either being a strong EMU country, being a weak EMU country, or in general adopting the euro in 1998. Table 3 presents the results of the estimation. The first panel reports results for the whole sample, and the second and third panels report results for large and small firms, respectively.

\section{[INSERT TABLE 3]}

Our having focused on the overall sample in model (1), our first important result is that firm value in the euro countries has increased 5.8\% more after 1997 than in non-euro countries. The coefficient is significant at the $10 \%$ level. The magnitude of the coefficient is important if we take into account that the average annual increase in $\mathrm{Q}$ over the whole sample period is $4.6 \%$. That is, ceteris paribus EMU-firms grew in value in 1998-2000 relative to the pre-euro period, while non-EMU firms destroyed value. Large firms enjoy a larger increase in Q (7.9\% increase in $\mathrm{Q}$ for large firms versus a $3.9 \%$ increase for small firms). This is consistent with the intuition that larger firms benefit more from integration, since large firms are more exposed to currency risks, and foreign investors prefer to invest in large firms (Dahlquist and Robertsson, 2001; Kang and Stulz, 1997).

We interact the euro-period dummy and the EMU-member dummy with the weak EMU dummy. Our results show, in line with Dumas and Solnik (1995), and Bodart and Reding (1999), that firms in countries with weaker currencies benefited more from the introduction of the euro. While firms in Finland, Italy, Ireland, Portugal, and Spain witnessed a 13.3\% increase in Q relative to non-euro countries after 1997, the same increase equals $3.4 \%$ for the strong EMU countries. We find similar results for the subsample 
of larger firms ( $13.8 \%$ versus $6.1 \%$ increase). For small firms however, the effect of the euro on value is insignificant for firms in the strong EMU area.

We find our controls to have the expected signs. As a measure of growth opportunities, size is negatively related to value. More profitable firms are more valuable (significant coefficients in all estimations at the $1 \%$ level). The ratio of tangible assets to total assets displays a negative and significant sign for small firms, and a positive and significant sign for large firms. For large firms we interpret the coefficient as an indication that the ability to monitor firms with tangible assets is valued by the market. For small firms, intangible assets are a proxy for growth opportunities. The domestic stock market return is positive and significantly related to Q, except for large firms.

\section{B Firm Value and the Exchange Rate Exposure}

Although all firms can benefit from the elimination of currency risks, the common currency should benefit firms even more to the extent that they are exposed to currency movements. For a firm whose suppliers operate in the local market, that sells only within a country's boundaries, and that finances its operations domestically, we deem the benefits of the euro to be smaller. Therefore, it is worth analyzing the effect of the common currency on firm value, depending on the firm's currency exposure, as calculated in section II.C. In Table 4 we present the results of the fixed effects model from the previous section with a further classification of firms into significantly positive, significantly negative, and insignificant ERB firms.

\section{[INSERT TABLE 4]}

We find that the more firms are exposed to exchange rate movements, the higher their gains from the introduction of the euro. For firms with significant currency exposure, the euro has induced an incremental $5.3 \%$ increase in Tobin's Q per year. The estimate for the overall effect of the euro becomes insignificant now, which demonstrates that the valuation effect of the common currency is relevant only to the extent that firms are exposed to currency risks. This effect is driven by negative exposure firms, as model (2) in Table 4 shows: these are firms that are harmed by a currency depreciation. Therefore, our results confirm that, by eliminating currency risks, the euro has made importing firms and firms that finance their operations using securities denominated in a foreign currency more valuable.

As before, results are even stronger for weak EMU firms. Column (4) in Table 4 shows that firms with negative (and significant) exposure to the euro, in weak EMU countries, have enjoyed a significant $22.3 \%$ increase in $Q$, relative to firms outside the euro-zone. For large firms we also find a positive effect of the monetary union on firms with positive exposure to the euro. These firms (mostly exporting firms) 
witnessed an average annual increase in $\mathrm{Q}$ of $10.1 \%$ with respect to non-exposed firms, and $17.9 \%$, relative to non-euro firms, after 1997.

To summarize - in the first part of the study we document a significant, sizeable effect of the euro on firm value. Such an effect is stronger for (i) larger firms, (ii) firms in countries that previously experienced currency depreciations, and (iii) firms with significant exposure to exchange rate movements, particularly those firms that were harmed by a depreciation of their own currency with respect to the euro.

\section{The Value of Euro Convergence}

The results that we presented in the previous section could be due to the introduction of the common currency, but also to macroeconomic developments caused by the oncoming monetary union. In fact, most of the countries that adopted the euro in 1999 went through a severe period of macroeconomic convergence. The Maastricht Treaty of February 1992 established the time frame and procedures for implementing a monetary union, including the determination of fiscal criteria required for EU members to qualify for the EMU. Our objective in this section is to determine the extent to which the valuation effects we have identified are driven by the euro itself, rather than by the convergence process that lowered interest rates, reduced budged deficits and government spending, and reduced inflation. Some of the changes the EMU countries implemented were actually dramatic: Belgium had a government deficit representing $8 \%$ of GDP in 1992. The deficit was $2 \%$ in 1998, and already in 2000 the budgetary position was completely balanced. Long-term interest rates went down in Spain from $14.7 \%$ in 1990 to $5.8 \%$ in 1997.

We therefore construct measures of euro convergence. Article 104c of the Maastricht Treaty assesses the degree of convergence achieved by the Member States by reference to the following criteria: ${ }^{8}$

1. Price stability: the average rate of inflation, observed over a period of one year before the examination, should not exceed by more than 1.5 percentage points that of, at most, the three best performing Member States in terms of price stability.

2. Government financial position: the deficit should not exceed $3 \%$ of the gross domestic product (GDP), unless it has declined substantially and continuously, and reached a level that comes close to $3 \%$. In addition, the public debt should not exceed $60 \%$ of GDP, unless it is sufficiently diminishing and approaching $60 \%$ at a satisfactory pace.

3. Observance of the (normal) fluctuation margins provided for by the Exchange Rate Mechanism of the European Monetary System (EMS), without severe tensions for at least two years. 
4. Durability of convergence: the average of the long-term interest rate, observed over a period of one year before the examination, should not exceed by more than 2 percentage points that of, at most, the three best performing Member States in terms of price stability.

We gather data on inflation, government deficit over GDP, long-term interest rates, and public debt over GDP from the Economist Intelligence Unit (EIU) database. We ignore convergence criterion (3) because it is already considered in our classification of countries into weak and strong EMU countries. We calculate convergence requirements for each of the macro variables, and calculate the position of each country, in each of the variables, during the years 1995 to 2000. If a country satisfies the corresponding convergence criterion, we assign a value of zero. Otherwise we compute the difference between the corresponding macro variable and the convergence requirements. The government budget convergence measure takes either zero or negative values. We calculate those for all the 15 countries in our sample, including the non-euro countries. In fact the U.K. and Denmark fully satisfied the convergence requirements in 1997, but they opted out of the system.

We also take into account changes in taxation. Indeed, corporate tax rates have declined in Europe over the period 1995-200 by an average 9.5\%. ${ }^{9}$ Interestingly, they have fallen more in EMU countries (an average of $11.38 \%$ ) than in non-EMU countries (5.8\% on average), with significant tax reductions in Ireland (where corporate tax rates have fallen from $36 \%$ in 1996 to $16 \%$ in 2000) and Italy (from $53.2 \%$ to 40.25). For every country and year, we calculate a dummy variable that equals 1 when the country reduces the nominal corporate tax rate with respect to the previous year, and zero otherwise.

\section{[INSERT TABLE 5]}

In Table 5 we show that the valuation effect we identify is driven by the common currency itself, not by the convergence process. The coefficient of the euro dummy becomes insignificant once we introduce the convergence criteria dummies. However, we still find that the euro yields positive valuation effects for large firms and for firms in the weak-EMU countries. The coefficients for the convergence criteria dummies are insignificant. One methodological reason for this is that we estimate standard errors clustered by country and year. Therefore the explanatory power of country and year-specific variables is small. In any case, our results are consistent with Henry (2002), who shows that there is no market response to lowering the inflation levels when the starting inflation rate is below $40 \%$. His sample includes 21 emerging markets. ${ }^{10}$ Taxation does not help explain valuation effects either, at least at the firm level. 


\section{The Effect of Cross-Border Mergers}

An alternative explanation for the increase in $\mathrm{Q}$ we document in the previous sections is an increase in the frequency of cross-border mergers. If currency risks within the euro zone have disappeared, then firms have become more valuable targets. The removal of separate national currencies encourages cross-border investment since the traditional reluctance of acquirors to make payments in another currency is no longer a factor. If high premia are paid in cross-border mergers, firms in Euroland will on average display market value increases.

In this section we attempt to identify the contribution of cross-border mergers to the positive valuation effect of the euro. In order to do this, we construct two measures of cross-border merger activity in the sample countries, using the data and methodology described in Bris and Cabolis (2002). The first measure is the ratio of the number of cross-border mergers of firms in a given country and year, divided by the total number of listed firms in such country. The second measure equals the euro value of all cross-border mergers of firms in a given country and year, divided by the country's market capitalization. Merger information is obtained from Securities Data Corporation and comprises a sample of 49 countries. Information on the number of listed firms and market capitalization is from the IFC manuals.

\section{[Insert TABLE 6]}

In Table 6 we aggregate the cross-border merger ratios by region. We classify countries into EMU, other European countries (the five countries in our non-EMU sample), and the rest of the world. We aggregate within-country measures of cross-border merger activity and calculate, for example, the ratio of other European firms that are acquired by EMU firms. Table 6 shows that, while the frequency of cross-border mergers of firms in the three regions increases, the largest increase happens in other European countries (116\% increase from 1995 to 2000, versus a $9.57 \%$ increase in the EMU, and $74.5 \%$ in the rest of the world). Results are similar in euro terms. ${ }^{11}$ Therefore, it does not seem that cross-border mergers of EMU targets by firms outside the Euroland have increased substantially after the introduction of the euro.

\section{[INSERT TABLE 7]}

We analyze now the effect of cross-border mergers on Tobin's Q in a panel regression. We include in the estimation described in section III.A the number of cross-border acquisitions of firms in a given country, divided by the total number of firms in that country. We prefer the number ratio rather than the value ratio because the latter is more affected by outliers. Results are in Table 7 . While the frequency of cross-border acquisitions affects Tobin's Q positively (the coefficients in the two models we estimate are 
0.261 and 0.355 , insignificant), the effect of the euro alone still remains: the coefficient of the euro dummy is 0.063 , significant at the $1 \%$ level. The magnitude of the coefficient is indeed larger now, confirming that cross-border mergers affect the value of non-Euro firms more than the value of Euro firms. Moreover, the effect of the euro continues to be larger for firms in weak EMU countries than form firms in strong EMU countries (the coefficients are 0.039 and 0.145 respectively, both significant at the $1 \%$ level). Once classified into weak-EMU and strong-EMU firms, the value of the larger firms in our sample is positively (and significantly at the 10\% level) affected by the frequency of cross-border mergers.

\section{Investments}

The previous results have two complementary interpretations. In principle, it is possible that the introduction of the euro has improved investment opportunities in Europe, resulting in higher Tobin's Q-ratios. We think that this effect is secondary. The main reason for this is that the process for the formation of single market in Europe was started in almost 15 years earlier. The White Paper outlining the regulatory changes needed for the creation of the single market was adopted in 1985. The adoption of the White Paper resulted in significant increases in foreign direct investments and mergers in Europe in the latter half of the 1980's (European Economy, 1997). Hence the improvement in investment opportunities due to creation of single market was over when the new currency was introduced.

While we believe that a direct increase in investment opportunities has been a secondary effect during the introduction of the common currency, investments should have increased in Europe. Elimination of currency risks reduces the cost of capital, ceteris paribus. In addition of elimination of currency risks, the euro has lead to further financial integration. As Bekaert and Harvey (1995) point out, more integration leads to a reduction in the cost of capital. This indirectly leads to an increase in investments because the range of acceptable investment projects increases. Changes in hurdle rates affect marginal investments, hence changes in the cost of capital have an ambiguous effect on marginal Q, and a positive effect on average Q. Under this interpretation, we should observe an increase in firm investments as a consequence of the common currency.

Table 8 shows the investment ratios for the firms in the sample, aggregated by country and by membership to the euro. Non-EMU firms invest significantly more in the pre-euro period. Only after 1998 are there no significant differences between euro and non-euro firms in terms of investments. Indeed, investment ratios in the two regions in 2000 are equal (7.6\% of assets). However, the average increase in investments from 1995 to 2000 is $105.41 \%$ in Euroland, and it decreases $15.56 \%$ for firms in non-EMU 
countries. From year-end 1997 to year-end 1998, investments increase 58.9\% in EMU countries, compared to a $30.35 \%$ in non-EMU firms. By country, the largest change in investments between 1995 and 2000 happens in Finland ${ }^{12}$ (1,114.29\% increase), the lowest in Sweden (32.32\% decrease). German companies invest 8.57\% more in 2000 than in 1995; U.K. firms invest 18\% less in 2000 than in 1995.

\section{[INSERT TABLE 8]}

In order to isolate the effects of the common currency, we specify a fixed effects model similar to the one in section III.A. We follow Kaplan and Zingales (1997) in the choice of control variables. We use the lagged Tobin's Q as a measure of investment opportunities and the ratio of EBITDA to total assets (previous year) as a measure of cashflow. Additionally, we control for the business cycle by means of the last-year GDP growth. Because of severe outliers, we winsorize the investment variable at the fifth and ninety-fifth percentiles. Because of winsorizing, our results are weaker, but still strongly significant, as we show in Table 9.

\section{[INSERT TABLE 9]}

We identify an incremental increase in investments in the Euroland of $3.3 \%$ per year with respect to non-euro countries, after 1997. The estimate is significant at the $1 \%$ level. Such an increase is larger for (i) larger firms (4.2\% increase for larger firms versus $2.2 \%$ increase in smaller firms), and (ii) firms in weak EMU countries (5.1\% increase versus 3.0\% increase in the strong EMU area). We additionally find a significant effect of the lagged Q: a $1 \%$ increase in Q predicts an increase in investments of $7.7 \%$ the following year. Similarly, we find that cashflow and investment are positively related.

As with $Q$ results, we analyze the effect of exchange rate sensitivity on investments in Table 10. We do not find a significant relationship between currency exposure and investment levels.

[INSERT TABLE 10]

\section{Capital Structure and the Euro}

\section{A Theory}

In this section we analyze the effects of the euro on firms' financial policies. In the previous sections we show that firms have become more valuable in Euroland because of a reduction in the cost of capital. In this section we study how these new investments have been financed. 
Consider the effects of the euro on corporate financial policies. Financial market integration allows foreign investors to have access to local securities with diversification potential, thus reducing the overall cost of capital (Bekaert and Harvey, 1995; Stulz, 1999). A reduction in the cost of capital implies a higher firm value. The predictions of the market integration literature are in line with the findings in this paper. However, as Stulz (1999) points out, a reduction in the cost of capital entails a reduction in the cost of equity as well as in the cost of debt. Because of differences in taxation, it is very difficult to analyze the effects of integration on the cost of debt in a cross-section of countries. Indeed, the empirical literature focuses solely on the cost of equity (see also Henry, 2000, and Errunza and Miller, 2002). Therefore, whether financial integration and cost of capital reductions lead to a preference of equity over debt, or vice versa, remains an unanswered question.

The first theories of capital structure assumed that firms were optimizing agents and that capital structure resulted from an optimal trade-off between bankruptcy and agency costs on one side and tax benefits on the other (Harris and Raviv, 1991). In this setting firms that experience positive shocks to their entity value (like the ones we report in section III.A) should adjust their debt-to-equity ratios so as to restore their optimal capital structure (Welch, 2002). If, as a result of the adoption of the euro, the optimal debt-to-equity ratios of the companies involved do not change, then a $5 \%$ increase in firm value should translate into a $5 \%$ increase in the amount of debt and a $5 \%$ in the amount of equity for a firm that was equally financed with debt and equity. The optimal trade-off effect of the euro thus encompasses proportional changes in debt and equity after the adoption of the common currency. This is our null hypothesis.

Alternatively, the euro can affect corporate financial policies via a whipsaw effect (Welch, 2002), whereby an increase in firm value reduces the market-based debt-to-equity ratio by its impact on the market value of equity, and increases a firm's debt capacity. A common currency influences the exposure of firms to exchange rate movements and therefore the riskiness of firms. The euro reduces currency fluctuations by eliminating currency risks within the currency area and hence leads to diminished risks for firms that once were exposed to those risks. The diminished risks imply a lower likelihood of financial distress and should lead to increased firm value, and thus higher corporate leverage (Bradley et al., 1984). We call this risk-reduction relationship the debt-capacity effect of the euro. Empirically, if this hypothesis is true, we should observe that the firms that once were exposed more to currency risks in the euro area should rely more on debt than on equity after adopting the common currency.

Another argument relies on the idea that a common currency is a credible commitment mechanism against currency devaluations. In an economy with fixed exchange rates, where devaluations are possible, 
it can be optimal ex post for the government to bail out financially distressed exporting firms by devaluing the currency. This gives firms an incentive to have an excessively high leverage (Bris and Koskinen, 2002). If this logic is true, we should observe empirically that financial policies of firms in the euro zone depend on their currency exposure: firms that benefit from currency depreciations should display higher debt ratios before the introduction of the euro and declining indebtedness afterwards. However, firms that are harmed by currency depreciations should not ceteris paribus change their financial policies around the introduction of the common currency. In this article we call this effect the strategic-leverage effect.

\section{B Results}

In Table 11 we present median changes in debt and net equity issuance by country, as well as by EMU membership. In general, our preliminary results support the view that firms rely on equity financing more when stock market returns are high (Loughran et al., 1994; Pagano et al., 1998). The largest increase in equity issuance in both EMU and non-EMU countries happens after 1998, coinciding with a period of high stock returns.

\section{[INSERT TABLE 11]}

A remarkable result in Table 11 is the explosion in the debt issuance by firms within the euro area after 1997. Debt issuance increases $3.4 \%$ in the euro area in 1998, compared to a $1.6 \%$ increase in 1997 . In nonEMU countries, debt issuance increases $3.3 \%$ in 1998 versus a $2.4 \%$ increase in 1997. Galati and Tsatsaronis (2001) document that such issuance activity was mostly dominated by corporate bonds denominated in euros that increased threefold coinciding with the debut of the euro in 1999. Equity issuance activity is more intense in non-EMU countries during the period 1995-2000. On average, non-EMU countries issue $0.09 \%$ more equity every year than the year before, compared to a $0.01 \%$ increase per year in Euroland. Finally, it seems that firms in both areas marginally issue more debt than equity. Table 11 also presents results by country, confirming a strong increase in debt issuance in 1998 in all countries (in particular, there are increases of $19.5 \%$ in Ireland, $10.3 \%$ in Norway, and $8.4 \%$ in the Netherlands). Equity financing is important in France, Belgium, and Finland.

We provide further evidence on the relationship between the euro and the financial decisions of firms in a fixed effects regression of debt and equity changes on firm characteristics and country controls. Among the variables suggested by the literature, we include the following:

1. Collateral value of assets. Titman and Wessels (1984) argue that firms with assets that can be used as collateral are expected to issue more debt. They proxy the collateral value of the assets with the 
ratio of tangible assets to total assets, as well as the ratio of inventory plus gross property, plant, and equipment to total assets. The relationship between measures of collateral value of assets and leverage are positively and significantly related. We believe that, by incorporating depreciation, the latter measure can be distorted by the firm's accounting practices. Therefore, our measure of collateral is the ratio of net property, plant, and equipment to total assets (lagged), as in Rajan and Zingales (1995). Our prior is that the relationship between debt issuance and tangibility of assets is positive and the relationship between equity issuance and tangibility of assets is negative.

2. Profitability. Myers and Majluf's (1984) pecking order theory predicts that firms that are able to retain earnings will rely on internal financing because of its insensitivity to informational asymmetries. Both Titman and Wessels (1984) and Rajan and Zingales (1995) measure profitability with the ratio of operating income to total assets and find a significant negative relationship. To account for differences in depreciation practices, we measure profitability with the lagged return on assets (EBITDA divided by total assets), as in Baker and Wurgler (2002).

3. Size. Larger firms should finance with debt more often if size is inversely related to the probability of bankruptcy. Size is usually measured as the logarithm of total assets. The literature consistently finds a positive relationship between size and leverage. In our model, we measure size as the log of current sales.

4. Growth. Firms with better growth opportunities find it more costly to finance with debt because of the agency costs of debt financing (Myers, 1977, Rajan and Zingales, 1995). However, firms with better growth opportunities, measured by the lagged market-to-book ratio, should invest more, and therefore need financing, be it debt or equity.

5. Past returns. Welch (2002) argues that the market valuation of a firm's equity determines corporate finance decisions. There are several papers that find that market valuations affect the decision to issue equity, or repurchase stock. ${ }^{13}$ We control in our regressions for the past return in the domestic stock market. We expect that higher past valuations result in lower current debt ratios.

6. Last year's Debt-to-Value ratio. Since we analyze changes in debt and equity issuance, we expect the past levels of indebtedness to affect the willingness of a firm to issue either instrument. We expect underlevered companies to issue more debt, and overlevered firms to issue equity.

We interact the EMU-membership dummy and the post-euro period dummy to measure the change in financial policy of firms in the euro zone, relative to the change in financial policy of firms that outside the 
euro zone. We also show results where we split the euro zone countries into two groups based on whether the country has suffered a currency devaluation in the period 1990-1997 (weak-EMU countries) or not (strong-EMU countries), since the effect of adopting the euro on financial decisions should be larger for firms in countries that are prone to currency crises.

We finally isolate firm-specific fixed effects, as well as time fixed effects, by using the corresponding dummies. Similar to the investment analysis, the dependent variables are winsorized to reduce the effects of outliers. The results of the estimation are shown in Table 12, where we report heteroskedasticity-consistent t-statistics.

\section{[INSERT TABLE 12]}

In Panel A we report the results on changes in debt issuance, and in Panel B we report results on equity issuance. We find that firms in the euro zone rely more on debt than on equity after 1998, and relative to non-EMU firms. Panel A documents a significant increase in debt issuance; in panel B there is no significant change in equity issuance, relative to non-EMU firms. There is no difference between large and small firms, although the result is dominated by firms in weak EMU countries. Note that our results here must be interpreted relative to non-euro countries. In section IV we document that firms in EMU countries invest 3.3\% more than non-EMU firms every year, after the adoption of the common currency. Panels A and B of Table 12 show that those investments are not financed with equity. Quite the opposite, panel A reports a $5.2 \%$ increase in debt issuance by firms in weak-EMU countries, $2.4 \%$ increase in strong-EMU countries. We therefore document an active debt policy, by which firms benefit from reductions in the riskiness of the assets, and consistent with the debt-capacity argument. Our analysis also shows that size does not determine a firm's preference for either debt or equity.

\section{[INSERT TABLE 13]}

Moreover, issuance of debt increases even after controlling for the past year leverage ratios. As predicted, the larger the last year's debt-to-equity ratio, the more equity is issued, and the less debt is issued, relative to non-EMU firms. This finding is consistent with a convergence process in indebtedness as well, as Table 13 documents. We report the median debt-to-value ratio by country and year. Although EMU firms had higher leverage than non-EMU firms, we show that firms in weak-EMU countries significantly increase their debt levels between 1998 and 2000. Indeed, while the debt ratio is in median $56.08 \%$ for firms in weak-EMU countries versus $66.22 \%$ in strong-EMU countries in 1997, the differences disappear in 2000 : $66.96 \%$ in weak-EMU firms versus $67.61 \%$ in strong-EMU firms. 


\section{Debt, Equity, and Currency Exposure}

We finally discuss the effects of currency exposure on firm financing decisions. Table 14 reports the result of the fixed effects estimation of changes in debt issuance (panel A) and changes in equity issuance (panel B), on the euro dummies, the controls specified in the previous section, and three dummies that capture the characteristics of the firms in our sample in terms of exchange rate beta.

The main finding of this section is that firms with positive exposure to intra-European currency risks rely on equity rather than debt financing. This result is partially consistent with Bris and Koskinen (2002) who argue that firms do not have incentives to use leverage as a strategic device any longer, because in EMU individual countries do not have the option to devalue. However, their model applies to a small country dominated by relatively large exporting firms. We instead find that, for the subgroup of large firms with positive currency exposure exporting firms-, financing is heavily dominated by debt rather than equity issuance, and it is for these firms for which the debt-capacity hypothesis finds a stronger support.

\section{[INSERT TABLE 14]}

To summarize - we do find strong support for the debt-capacity hypothesis in firms that were more exposed to currency risks before the introduction of the euro: firms in countries that suffered currency devaluation in the pre-euro period, large firms, and firms that would be harmed by depreciations of their own currency with respect to the euro.

\section{Robustness Checks}

To test the robustness of our findings, we first document that the positive effect of the euro is significant after controlling for the depreciation of the euro with respect to the U.S. dollar. Next we exclude Germany and the U.K. from the analysis. We then examine the sensitivity of the results to the choice of the event year. All tables corresponding to this section are in Appendix B.

\section{A The Impact of the Dollar}

Over the period January 1998, December 2000, the euro depreciated 25\% with respect to the dollar. In the paper we do not control for dollar exposure. Therefore, it is possible that our findings result from a significant exposure of firms in the Euroland to the dollar, and not to the euro. If this hypothesis were to be true, then changes in the relative price of the euro with respect to the dollar would explain changes in firm valuation within the Euro area. 
[INSERT TABLE B1]

We analyze the impact of the dollar on Tobin's Q in Table B1. We gather data on the exchange rate domestic currency / U.S. dollar during the sample period from Datastream. After 1998, the exchange rate for each EMU country is implicitly obtained from the euro-dollar exchange rate. We then calculate the change in the exchange rate for each country and year in the sample. The coefficient for this variable is insignificantly different from zero for the overall sample, as well as for the subsamples of small and large firms. $^{14}$

\section{B Excluding Germany and the U.K.}

Table 2 shows that firms from Germany account for $44.79 \%$ of the sample of EMU firms. Similarly, U.K. firms represent $79.43 \%$ of the observations from non-EMU countries. Therefore one could conclude that our results do not reflect differences in valuation between Euro and non-Euro countries, but between German and British firms instead.

In Table B2 we demonstrate that this is not the case. Although the sample size drops to only 3,888 firm-year observations, even when we exclude German and British firms from the Tobin's Q regressions, we still find a positive and significant effect of the euro on firm value. For the overall sample, Tobin's Q increases a 5.5\% more every year in EMU than in non-EMU firms, after 1997. We still find that the effect is more pronounced in weak-EMU countries than in the strong-EMU countries. However, by removing Germany and the U.K., we do not find size to be a determinant effect of the relationship between the euro and Tobin's Q.

\section{[INSERT TABLE B2]}

It is not the case that large firms are only German firms, since we classify firms into large and small depending on the median size in each country. We interpret this result in the following way. Germany and the U.K. are not only the countries that contribute with more firms to the sample, but are also the largest economies. Small firms in these countries are the are able to operate in their home market, because it is larger, while small firms in the remaining countries are forced to operate internationally to a greater extent. That is why the effect of the euro is also positive for small firms in small EMU countries. 


\section{The Date of the Adoption of the Euro}

Finally, our last robustness check concerns the choice of the event date for our study. We deem 1998 to be the year in which there was a consensus of the countries that would join the EMU. In any case, it is possible that markets perfectly anticipated such an event earlier. It is also possible that markets reacted late to the introduction of the common currency, and our results understate the real effects of the common currency.

We regress in Table B3 the Tobin's Q in our sample of firms on five dummy variables. Each dummy variable takes the value 1 for firms in the Euroland, and in years 1996, 1997, 1998, 1999, and 2000 respectively. Therefore, the coefficient of each of the dummy variables represents the impact of the euro on firm value, in each of the corresponding years.

\section{[INSERT TABLE B3]}

We find strong support for our hypothesis that 1998 is the year when the effect of the common currency is impounded into market values. In one single year, the average firm in the Euroland increases market value by $13.1 \%$ relative to non-EMU firms. Large firms increase value even further $(14.2 \%$ increase compared to $12.3 \%$ for small firms).

\section{Conclusion}

Economic and Monetary Union and the adoption of a common currency for 12 countries within the Union is a major social experiment that has also significant financial implications. This article is a first attempt to study the effects of the euro on firm value, investments, and corporate financial decisions. We use corporatelevel data from ten countries that adopted the euro. We exclude Greece and Luxembourg because of lack of data. We also use data from the three EU countries (Denmark, Sweden, and the U.K.) that did not join EMU, as well as Norway and Switzerland. We show that valuations for large firms have grown by $7.9 \%$ in the period 1998-2000 in the Euroland compared to the five non-EMU countries.

We provide evidence that the effects of the euro have been bigger for firms that were more exposed to exchange rate risk before the adoption of the common currency: firms from countries with previously weak currencies - defined as those countries that suffered currency crises in the early nineties - and firms whose value decreased when their domestic currencies depreciated with respect to the euro. This suggests that the underlying reason for the value increases has been a reduction in currency risks that has consequently 
reduced firms' cost of capital. In principle, it is possible that the adoption of euro could have increased market risk in Europe, because authorities in individual countries now lack instruments to respond to asymmetric shocks. However, we do not find any support for this view. In addition, Bartram et al. (2002) document declining market risk for firms exposed to European risks, further strengthening our results and interpretations.

An additional argument for why euro countries have witnessed a significant positive development in the corporate sector is tax reductions. Our results, however, hold even when we consider changes in taxation in the countries we study. We also show that firms have increased value as an effect of the euro itself, not as a consequence of the severe macroeconomic convergence process some of the countries in the euro zone had to go through. Another alternative explanation for the value increases we document is cross-border acquisitions. We show that, while there is a positive relationship between the frequency of cross-border mergers and Tobin's Q in the Euroland, most of the gains from the common currency come from a reduction in the firms' cost of capital. Finally, because we use a control sample of five non-EMU countries, we are able to reject the possibility that the business cycle and the high stock prices in the late 1990's are the reasons for increases in firm value.

Our paper also shows that increases in Tobin's Q have translated into more investments by firms in the euro zone. Euro firms have invested 3.3\% more of their assets in the period 1998-2000 than non-euro firms. The magnitude of the effect is substantial, if one takes into account that euro-firms have invested $6.1 \%$ of their assets per year in the same period. The effect of the euro on firm investments is larger for larger firms and for firms in weak EMU countries. However, we do not find evidence that a firm's exposure to currency risks determines changes in investment policy.

Finally, our paper analyzes how such increases in investments have been financed. We document that firms in the euro countries in general have increased their book-based leverage in the years 1998-2000 compared to non-EMU firms. We confirm this finding in panel regressions showing that the investments have been financed by debt, suggesting that firms' capacity to bear debt has increased. The increase in debt-capacity is again consistent with our interpretation that firms' risks have been reduced because of the introduction of the common currency.

We have documented significant increases in corporate valuations and investments that are due to the introduction of the euro. Do these results imply that all European countries should join EMU? It might be tempting to say yes, but as in economics in general, the right answer should be that it depends. If a country's firms are exposed to euro risks, then the answer should be yes. If, for example, the country's firms are more exposed to the dollar, then the loss of monetary independence might be too high of a price 
to pay for the benefits of the common currency. 


\section{References}

Adler Michael, and Bernard Dumas, 1983, International Portfolio Choice and Corporation Finance: A Synthesis, Journal of Finance 38, 925-984.

Amihud, Yakov, 1994, Exchange Rates and the Valuation of Equity Shares, in Y. Amihud and R M. Levich (eds.), Exchange Rates and Corporate Performance (Irwin, New York), 49-59.

Baker Malcolm, and Jeffrey Wurgler, 2002, Market Timing and Capital Structure, Journal of Finance $57,1-32$.

Bartram, Söhnke, G. Andrew Karolyi, and Stefanie Kleimeier, 2002, The Impact of the euro on Foreign Exchange Risk Exposures, mimeo.

Bekaert, Geert, and Campbell Harvey, 1995, Time-Varying World Market Integration, Journal of Finance $50,403-444$

Bodart, Vincent, and Paul Reding, 1999, Exchange Rate Regime, Volatility and International Correlations of Bond and Stock Markets, Journal of International Money and Finance 18, 133-151.

Bodnar, Gordon M., and W. Gentry, 1993, Exchange rate exposure and industry characteristics: Evidence from Canada, Japan, and the US, Journal of International Money and Finance 12, 29-45.

Bodnar, Gordon M., and M.H. Franco Wong, 2000, Estimating Exchange Rate Exposures: Some "Weighty" Issues, NBER Working Paper No. W7497.

Bradley, Michael, Gregg A. Jarrell, and E. Han Kim, 1984, On the Existence of an Optimal Capital Structure, Journal of Finance 39, 857-878.

Bris, Arturo, and Christos Cabolis, 2002, Corporate Governance Convergence by Contract: Evidence from Cross-Border Mergers', working paper.

Bris, Arturo, and Yrjö Koskinen, 2002, Corporate Leverage and Currency Crises, Journal of Financial Economics 63, 275-310.

Bris, Arturo, Yrjö Koskinen, and Vicente Pons, 2002, Corporate Financial Policies around Currency Crises, Journal of Business, forthcoming.

Cooper, Ian, and Evi Kaplanis, 1994, Home Bias in Equity Portfolios, Inflation Hedging, and International Capital Market Equilibrium, Review of Financial Studies 7, 45-60. 
Dahlquist, Magnus, and Göran Robertsson, 2001, Direct Foreign Ownership, Institutional Investors, and Firm Characteristics, Journal of Financial Economics 59, 413-440.

Danthine, Jean-Pierre, Francesco Giavazzi, and Ernst-Ludwig von Thadden, 2000, European Financial Markets after EMU: A First Assessment, Discussion Paper No. 2413, CEPR.

De Santis, Giorgio, and Bruno Gerard, 1998, How Big is the Premium for Currency Risk?, Journal of Financial Economics 49, 375-412.

De Santis, Giorgio, Bruno Gerard, and Pierre Hillion, 1999, The European single currency and word equity markets, in J.Dermine and P.Hillion (eds.), European Capital Markets with a Single Currency, Oxford University Press.

Dumas, Bernard, and Bruno Solnik, 1995, The World Price of Foreign Exchange Risk, Journal of Finance $50,445-479$.

Errunza, Vihang, and E. Losq, 1985, International Asset Pricing Under Mild Segmentation: Theory and Test, Journal of Finance 40, 105-124.

Errunza, Vihang, and Darius Miller, 2002, Market Segmentation and the Cost of Capital in International Equity Markets, Journal of Financial and Quantitative Analysis, 577-600.

Eun, C.S. and J. Janakiramanam, 1986, A Model of International Asset Pricing with a Constraint on the Foreign Equity Ownership, Journal of Finance 41, 897-914.

European Economy, 1997.

French, Kenneth, and James Poterba, 1991, Investor Diversification and International Equity Markets, American Economic Review 81, 222-226.

Galati, Gabriele, and Kostas Tsatsaronis, 2001, The Impact of the euro on Europe's Financial Markets, BIS working paper no. 100.

Hardouvelis, Gikas A., Dimitrios Malliaropoulos, and Richard Priestley, 2001, EMU and European Stock Market Integration, working paper.

Henry, Peter B., 2000, Stock Market Liberalization, Economic Reform, and Emerging Market Equity Prices, Journal of Finance 55, 529-564.

Henry, Peter B., 2002, Is Disinflation Good for the Stock Market?, Journal of Finance, forthcoming. 
Honkapohja, S., and E. Koskela, 1999. The economic crisis of the 1990's in Finland. Economic Policy 4, 401-436.

Jorion Philippe, 1990, The Exchange Rate Exposure of US Multinationals, Journal of Business 63, 331-345.

Jorion Philippe, 1991, The Pricing of Exchange Rate Risk in the Stock Market, Journal of Financial and Quantitative Analysis 26, 363-376.

Jung, Kooyul, Yong Cheol Kim, and Rene M. Stulz, 1996, Timing, investment opportunities, managerial discretion, and the security issue decision, Journal of Financial Economics 42, 159-185.

Kang, Jun-Koo, and René Stulz, 1997, Why Is There a Home Bias? An Analysis of Foreign Portfolio Equity Ownership in Japan, Journal of Financial Economics 46, 3-28.

Kaplan Steven N., and Luigi Zingales, 1997, "Do Investment-Cash Flow Sensitivities Provide Useful Measures of Financing Constraints?", Quarterly Journal of Economics 112, 169-216.

Lewis, K., 1999, Trying to Explain Home Bias in Equities and Consumption, Journal of Economic Literature 37, 571-608.

Loughran, Tim, Jay Ritter, and Kristian Rydqvist, 1994, Initial Public Offerings: International insights, Pacific-Basin Finance Journal 2, 165-199.

McConnell, John, and Henri Servaes, 1990, Additional evidence on equity ownership and corporate value, Journal of Financial Economics 27, 595-612.

Merton R., 1987, Presidential Address: A Simple Model of Capital Market Equilibrium with Incomplete Information, The Journal of Finance 42, 483-510.

Myers, Stewart, and Nicholas Majluf ,1984, Corporate Financing and Investment Decisions when Firms Have Information that Investors Do Not Have, Journal of Financial Economics 13, 187-221.

Pagano, Marco, Fabio Panetta, and Luigi Zingales, 1998, Why Do Companies Go Public? An Empirical Analysis, Journal of Finance 53, 27-64.

Rajan Raghuram G. and Luigi Zingales, 1995, What Do We Know about Capital Structure? Some Evidence from International Data, Journal of Finance 50, 1421-1460. 
Rouwenhorst, K. Geert, 1999, European Equity Markets and EMU: Are the Differences between Countries Slowly Disappearing?, Financial Analyst Journal.

Santos, Joao, and Kostas Tsatsaronis, 2002, The Cost of Barriers to Entry: Evidence from the Market for Corporate euro Bond Underwriting, mimeo.

Solnik, B., 1974, An Equilibrium Model of the International Capital Market, Journal of Economic Theory 8, 500-524.

Stulz, R., 1981, On the Effects of Barriers to International Investment, The Journal of Finance 36, 923-934.

Stulz, René, 1999, Globalization of Capital Markets and the Cost of Capital, Journal of Applied Corporate Finance, Fall , 8-25.

Stulz R., and W. Wasserfallen, 1995, Foreign Equity Investment Restrictions, Capital Flight, and shareholder wealth Maximization: Theory and Evidence, Review of Financial Studies 8, 1019-1057.

Tesar, Linda, and Ingrid Werner, 1995, Home Bias and High Turnover, Journal of International Money and Finance 14, 467-492.

Titman, Sheridan, and Roberto Wessels, 1988, The Determinants of Capital Structure Choice, Journal of Finance 43, No. 1. 1-19.

Welch, Ivo, 2002, Columbus' Egg: The Real Determinant of Capital Structure, Yale ICF Working Paper 02-03. 


\section{A Appendix A: Exchange Rate Exposure Calculation}

We characterize firms by their responses to exchange rate movements. To that end, we calculate exchange rate betas for the firms in our sample. In this section we describe the procedure.

A commonly used method of calculating a firm's exposure to currency risk is to estimate the following regression:

$$
R_{i j t}=\alpha_{i}+\varpi_{i} R_{m t}^{j}+\beta_{i}^{x} R_{x t}^{j}++u_{i j t},
$$

where $R_{i j}$ is the stock return of firm $i$ in country $j, R_{m}^{j}$ is the monthly return on the domestic market portfolio in country $j, R_{x}^{j}$ is the monthly change in the exchange rate in country $j$, and the $\beta_{i}^{x}$ 's are then measures of currency exposure. Such an approach is used by Jorion (1990), Bodnar and Gentry (1993), and Amihud (1994). Jorion (1991) uses a version of this two-factor model, in which the return of the market portfolio is the first factor and the component of innovations in the exchange rate that is orthogonal to the market return is the second factor. However the procedure affects only the estimates of the market beta, not the exchange rate exposures. Therefore, we follow the simple method of Jorion (1990). We estimate the model in (3) using monthly data from January 1992 through December $1994 .{ }^{15}$ We purposely choose an estimation period that is before our sample period, in order to avoid potential endogeneity problems.

We calculate exchange rate betas (ERBs) with respect to the euro. Although the euro existed only after January 1, 1999, Datastream computes a synthetic euro rate based on the weights each currency has in the real euro. The exchange rates are expressed as units of domestic currency per euro. Because some firms lack stock return data before 1995, the ERB sample is smaller than our original sample.

Our results are robust to choice of the estimation method for the exposure coefficients. We have performed the estimation by using the method in Jorion (1991) and Bris et al. (2002). They propose a two-step method, in order to eliminate the exchange rate exposure of the market return itself. Here, we first estimate the regression:

$$
R_{m t}^{j}=\gamma_{o}^{j}+\gamma_{1}^{j} R_{x t}^{j}+\nu_{s t}^{j} \quad \forall j=1, \ldots, 15
$$

and then estimate exposure by using the orthogonal component of the market return, $F_{m t}^{j}=R_{m t}^{j}-\left(\widehat{\gamma}_{o}^{j}+\right.$ $\left.\widehat{\gamma}_{1}^{j} R_{x t}^{j}\right)$, in a firm-level regression:

$$
R_{i j t}=\delta_{i}+\beta_{i}^{x} R_{x t}^{j}+\beta_{i}^{m} F_{m t}^{j}+\epsilon_{i j t}
$$


Note that, if the $\widehat{\gamma}_{1}$ coefficients are not significantly different from zero, the orthogonalization induces an error-in-variables problem, and the variance of $\widehat{\beta}_{i}^{x}$ will be inflated. Therefore, we calculate $F_{m t}$ with $\widehat{\gamma}_{1}=0$ when its significance level is higher than $5 \%$. This happens for all but three countries: Denmark, Sweden, and the U.K.. Therefore, for 12 out of 15 countries in our sample, the ERB estimates collapse to the ones we obtain following Jorion (1990), and there is no qualitative change in the results with respect to the ones we report in the paper. 


\section{Notes}

1. For more detailed descriptions of the developments, see Galati and Tsatsaronis (2001).

2. Greece is excluded due to lack of data and because it was admitted to EMU in June 2000, more than two years after the other countries. Luxembourg is excluded only because of lack of data.

3. Danthine et al. (2000) report that in a poll taken in January 1998 and covering over 200 financial and economic forecasters, all the countries that would adopt the euro in January 1999 received a minimum of $94 \%$ positive responses and in most cases the responses were $100 \%$ positive.

4. The White Paper proposing the completion of the single market in Europe was adopted in 1985 and the measures creating the single market were in place by 1992.

5. Lewis (1999) provides an extensive recent survey of the home bias literature.

6. The variables are : Tobin's $Q$, the book value of total assets, the book value of fixed tangible assets, and earnings before interest, taxes, depreciation, and amortization (EBITDA).

7. In the autumn of 1992 a wave of speculative attacks hit the European exchange rate mechanism (ERM) and its periphery. Before the end of the year, five countries (Finland, Italy, Norway, Sweden, and the U.K.) had floated their currencies. Despite attempts by a number of countries to remain in the ERM with the assistance of devaluations (Ireland, Portugal, and Spain), the system was unsalvageable.

8. The text of the Treaty is available at http://europa.eu.int/en/record/mt/top.html

9. Data on corporate tax rates in Europe are from KPMG Corporate Tax Rate Survey, 1995-2001.

10. Although not reported here, we also regress Tobin's $\mathrm{Q}$ on the values of the macro variables themselves, without adjusting for convergence. The long-term interest rate displays an negative and significant coefficient. The government budget deficit has a negative sign, and it is significant at the $10 \%$ level.

11. In 1999, $4.38 \%$ of the EMU market capitalization was acquired by European, non-EMU acquirors. This is caused by the acquisition of German Mannesmann AG by U.K. Vodafone AirTouch PLC in November 1999. The value of this acquisition was $\$ 202$ million.

12. Finland went to a depression in the early nineties as a consequence of the collapse of its major trading parter, the Soviet Union, and the sharp rise in European interest rates. Finland's real GDP dropped by 
about $14 \%$ from its peak in 1990 to 1993 . By 1994 unemployment had reached nearly $20 \%$, up from $3 \%$ four years earlier. See Honkapohja and Koskela (1999).

13. See Baker and Wurgler (2002) for detailed references.

14. This specification is similar to regressing Tobin's $Q$ on the change in the exchange rate euro-dollar, but it allows for more within-country variation.

15. If there are fewer than 18 observations available per firm, we exclude it from the estimation. 
Table 1. Euro exchange rate exposure

The euro exchange rate exposure is measured as the exchange rate beta from a two-factor model of stock returns in which changes in the (synthetic) euro exchange rate and the domestic stock market return are the two factors. The estimations of exchange rate betas are performed using monthly data over the time period January 1992 to December 1994. All data is from DataStream. The \% Significant is based on significance at the 5\%-level using onesided t-tests of the exchange rate betas.

\begin{tabular}{|c|c|c|c|c|c|c|}
\hline \multirow[b]{2}{*}{ Country } & \multirow[b]{2}{*}{$\mathrm{N}$} & \multirow{2}{*}{$\begin{array}{c}\text { Median } \\
\text { Exchange } \\
\text { Rate Beta }\end{array}$} & \multicolumn{2}{|c|}{ Positive Exchange Rate Beta } & \multicolumn{2}{|c|}{ Negative Exchange Rate Beta } \\
\hline & & & $\%$ Firms & $\%$ Significant & $\%$ Firms & $\%$ Significant \\
\hline \multicolumn{7}{|c|}{ EMU-countries: } \\
\hline Germany & 370 & 0.09 & 55.4 & 10.2 & 43.0 & 10.9 \\
\hline Belgium & 27 & -0.02 & 40.7 & 9.1 & 57.7 & 0.0 \\
\hline Spain & 39 & -0.24 & 43.6 & 17.6 & 50.0 & 13.6 \\
\hline Finland & 34 & -0.21 & 41.2 & 21.4 & 63.6 & 15.0 \\
\hline France & 148 & 0.20 & 55.4 & 11.0 & 37.9 & 9.1 \\
\hline Ireland & 9 & -0.21 & 33.3 & 0.0 & 66.7 & 0.0 \\
\hline Italy & 41 & -0.34 & 36.6 & 6.7 & 63.4 & 30.8 \\
\hline Netherlands & 60 & 0.90 & 78.3 & 23.4 & 21.7 & 0.0 \\
\hline Austria & 38 & -0.31 & 31.6 & 8.3 & 68.4 & 19.3 \\
\hline Portugal & 37 & 0.54 & 75.7 & 14.3 & 24.3 & 0.0 \\
\hline Total & 803 & 0.09 & 54.0 & 11.9 & 46.0 & 11.8 \\
\hline \multicolumn{7}{|c|}{ Non-EMU countries: } \\
\hline Denmark & 33 & -0.05 & 48.5 & 37.5 & 51.5 & 0.0 \\
\hline Norway & 42 & 0.03 & 52.4 & 18.2 & 47.6 & 15.0 \\
\hline Sweden & 61 & -0.48 & 34.4 & 28.6 & 65.6 & 22.5 \\
\hline Switzerland & 63 & 0.05 & 50.8 & 9.4 & 49.2 & 9.7 \\
\hline UK & 771 & -0.50 & 24.0 & 5.4 & 76.0 & 21.2 \\
\hline Total & 970 & -0.41 & 28.5 & 10.5 & 71.5 & 20.0 \\
\hline
\end{tabular}


Table 2. Median Tobin's Q 1995-2000

The table displays median Tobin's Q over the time-period 1995-2000 for all firms from the EMU-countries (except Luxembourg and Greece) and five Non-EMU countries (Denmark, Norway, Sweden, Switzerland, and UK) with data available in DataStream for at least the time period 1995-1998. The Tobin's Q is defined as the sum of the market value of common equity and the book value of total non-equity liabilities divided by the book value of total assets. The Wilcoxon rank-sum test in Panel A tests if the median Tobin's Q for EMU-countries is equal to the median Tobin's Q for Non-EMU countries for each year. All data is collected from DataStream

Panel A: EMU vs. Non-EMU countries

\begin{tabular}{lcccccc}
\hline & \multicolumn{7}{c}{ Median Tobin's Q } \\
\hline EMU-countries & 1995 & 1996 & 1997 & 1998 & 1999 & 2000 \\
$\quad$ Number of firms & 1.15 & 1.18 & 1.27 & 1.26 & 1.23 & 1.21 \\
& 884 & 884 & 884 & 884 & 853 & 786 \\
Non-EMU-countries & 1.36 & 1.39 & 1.37 & 1.19 & 1.27 & 1.21 \\
$\quad$ Number of firms & 1,104 & 1,104 & 1,104 & 1,104 & 972 & 801 \\
\hline Wilcoxon rank-sum test & 7.59 & 7.99 & 3.62 & 3.52 & 0.60 & 0.36 \\
(p-value) & $(<0.001)$ & $(<0.001)$ & $(<0.001)$ & $(<0.001)$ & $(0.552)$ & $(0.717)$ \\
\hline
\end{tabular}

Panel B: Individual countries

\begin{tabular}{|c|c|c|c|c|c|c|}
\hline & \multicolumn{6}{|c|}{ Median Tobin's Q } \\
\hline & 1995 & 1996 & 1997 & 1998 & 1999 & 2000 \\
\hline \multicolumn{7}{|l|}{ EMU-countries: } \\
\hline Germany & 1.27 & 1.22 & 1.30 & 1.30 & 1.26 & 1.25 \\
\hline Number of firms & 396 & 396 & 396 & 396 & 380 & 334 \\
\hline Belgium & 1.13 & 1.29 & 1.40 & 1.41 & 1.44 & 1.27 \\
\hline Number of firms & 30 & 30 & 30 & 30 & 30 & 29 \\
\hline Spain: & 1.14 & 1.16 & 1.36 & 1.53 & 1.42 & 1.30 \\
\hline Number of firms & 40 & 40 & 40 & 40 & 39 & 39 \\
\hline Finland: & 0.94 & 1.02 & 1.15 & 1.01 & 1.04 & 1.04 \\
\hline Number of firms & 52 & 52 & 52 & 52 & 52 & 52 \\
\hline France: & 1.10 & 1.15 & 1.18 & 1.21 & 1.21 & 1.19 \\
\hline Number of firms & 164 & 164 & 164 & 164 & 156 & 152 \\
\hline Ireland: & 1.17 & 1.33 & 1.51 & 1.28 & 1.23 & 1.28 \\
\hline Number of firms & 9 & 9 & 9 & 9 & 9 & 9 \\
\hline Italy: & 0.98 & 0.96 & 1.09 & 1.15 & 1.15 & 1.18 \\
\hline Number of firms & 41 & 41 & 41 & 41 & 40 & 40 \\
\hline Netherlands: & 1.39 & 1.56 & 1.78 & 1.53 & 1.42 & 1.44 \\
\hline Number of firms & 66 & 66 & 66 & 66 & 66 & 60 \\
\hline Austria: & 1.10 & 1.16 & 1.13 & 1.15 & 1.08 & 1.05 \\
\hline Number of firms & 46 & 46 & 46 & 46 & 45 & 45 \\
\hline Portugal: & 1.00 & 1.01 & 1.11 & 1.09 & 0.99 & 1.05 \\
\hline Number of firms & 40 & 40 & 40 & 40 & 36 & 26 \\
\hline \multicolumn{7}{|c|}{ Non-EMU-countries: } \\
\hline Denmark: & 1.16 & 1.43 & 1.38 & 1.09 & 1.14 & 1.15 \\
\hline Number of firms & 35 & 35 & 35 & 35 & 35 & 34 \\
\hline Norway: & 1.22 & 1.34 & 1.59 & 1.12 & 1.09 & 1.10 \\
\hline Number of firms & 48 & 48 & 48 & 48 & 48 & 47 \\
\hline Sweden: & 1.15 & 1.19 & 1.38 & 1.32 & 1.20 & 1.23 \\
\hline Number of firms & 77 & 77 & 77 & 77 & 75 & 65 \\
\hline Switzerland & 1.01 & 1.04 & 1.10 & 1.14 & 1.17 & 1.23 \\
\hline Number of firms & 67 & 67 & 67 & 67 & 67 & 66 \\
\hline UK & 1.45 & 1.45 & 1.38 & 1.21 & 1.34 & 1.22 \\
\hline Number of firms & 877 & 877 & 877 & 877 & 747 & 589 \\
\hline
\end{tabular}


Table 3. The introduction of the euro and firm value: Fixed firm-effects regression analysis

The sample covers the time period 1995-2000 and includes all firms from the EMU-countries (except Luxembourg and Greece) and five Non-EMU countries (Denmark, Norway, Sweden, Switzerland, and UK) with data available in DataStream for at least the time period 1995-1998. The dependent variable is the log of the Tobin's Q, defined as the sum of the book value of non-equity liabilities and the market value of common equity divided by the book value of total assets. The post-euro time period is defined as years 1998-2000. The EMU-countries classified as weak (i.e., countries with a recent currency crisis) are: Finland, Italy, Ireland, Portugal and Spain. A firm is classified as large if its book value of total assets in 1995 is above the median book value of total assets among sample firms from the same country and year; otherwise it is classified as a small firm. T-statistics based on robust standard errors adjusted for firm dependence within country-years are reported within parentheses. *,**, and ***, denotes significance at the $10 \%, 5 \%$, and $1 \%$-levels, respectively.

\begin{tabular}{|c|c|c|c|c|c|c|}
\hline \multirow[b]{2}{*}{ Explanatory Variable: } & \multicolumn{2}{|c|}{ All firms } & \multicolumn{2}{|c|}{ Large firms } & \multicolumn{2}{|c|}{ Small firms } \\
\hline & $(1)$ & (2) & (3) & (4) & $(5)$ & (6) \\
\hline EMU-country x post-euro time period & $\begin{array}{c}0.058 * \\
(1.75)\end{array}$ & & $\begin{array}{c}0.079 * * * \\
(2.74)\end{array}$ & & $\begin{array}{l}0.039 \\
(0.95)\end{array}$ & \\
\hline Strong EMU-country x post-euro time period & & $\begin{array}{l}0.034 \\
(0.96)\end{array}$ & & $\begin{array}{c}0.061 * * \\
(2.02)\end{array}$ & & $\begin{array}{l}0.009 \\
(0.20)\end{array}$ \\
\hline Weak EMU-country x post-euro time period & & $\begin{array}{c}0.133 * * * \\
(3.59)\end{array}$ & & $\begin{array}{c}0.138 * * * \\
(3.96)\end{array}$ & & $\begin{array}{c}0.132 * * * \\
(2.79)\end{array}$ \\
\hline Log of sales (in euro) & $\begin{array}{c}-0.101 * * * \\
(-6.35)\end{array}$ & $\begin{array}{c}-0.103 * * * \\
(-6.53)\end{array}$ & $\begin{array}{c}-0.075^{* * * *} \\
(-6.07)\end{array}$ & $\begin{array}{c}-0.077 * * * \\
(-6.20)\end{array}$ & $\begin{array}{c}-0.120 * * * \\
(-5.91)\end{array}$ & $\begin{array}{c}-0.122 * * * \\
(-6.09)\end{array}$ \\
\hline EBITDA/ total assets & $\begin{array}{c}0.470 * * * \\
(5.22)\end{array}$ & $\begin{array}{c}0.470 * * * \\
(5.21)\end{array}$ & $\begin{array}{c}0.729 * * * \\
(6.22)\end{array}$ & $\begin{array}{c}0.731 * * * \\
(6.23)\end{array}$ & $\begin{array}{c}0.362 * * * \\
(3.69)\end{array}$ & $\begin{array}{c}0.360 * * * \\
(3.67)\end{array}$ \\
\hline Fixed tangible assets / total assets & $\begin{array}{l}-0.018 \\
(-0.21)\end{array}$ & $\begin{array}{l}-0.017 \\
(-0.19)\end{array}$ & $\begin{array}{c}0.231 * \\
(1.92)\end{array}$ & $\begin{array}{c}0.232 * \\
(1.92)\end{array}$ & $\begin{array}{c}-0.194 * * \\
(-2.24)\end{array}$ & $\begin{array}{c}-0.192 * * \\
(-2.21)\end{array}$ \\
\hline Current year real GDP growth & $\begin{array}{c}3.673 * * * \\
(3.02)\end{array}$ & $\begin{array}{c}4.139 * * * \\
(3.34)\end{array}$ & $\begin{array}{c}3.404 * * * \\
(3.23)\end{array}$ & $\begin{array}{c}3.738 * * * \\
(3.52)\end{array}$ & $\begin{array}{c}3.807 * * * \\
(2.58)\end{array}$ & $\begin{array}{c}4.427 * * * \\
(2.93)\end{array}$ \\
\hline Current year domestic stock market returns & $\begin{array}{c}0.079 * * \\
(2.51)\end{array}$ & $\begin{array}{c}0.064 * \\
(1.83)\end{array}$ & $\begin{array}{l}0.047 \\
(1.41)\end{array}$ & $\begin{array}{l}0.035 \\
(0.91)\end{array}$ & $\begin{array}{c}0.111 * * * \\
(2.92)\end{array}$ & $\begin{array}{c}0.093 * * \\
(2.42)\end{array}$ \\
\hline Year dummies & Yes & Yes & Yes & Yes & Yes & Yes \\
\hline Adjusted $\mathrm{R}^{2}$ & 0.735 & 0,736 & 0.765 & 0.766 & 0.716 & 0.717 \\
\hline Number of firm-year observations & 10,332 & 10,332 & 5,124 & 5,124 & 5,208 & 5,208 \\
\hline
\end{tabular}


Table 4. The introduction of the euro, exchange rate exposure, and firm value: Fixed firm-effects regression analysis

The sample covers the time period 1995-2000 and includes all firms from the EMU-countries (except Luxembourg and Greece) and five Non-EMU countries (Denmark, Norway, Sweden, Switzerland, and UK) with data available in DataStream for at least the time period 1995-1998. The dependent variable is the log of the Tobin's Q, defined as the sum of the book value of non-equity liabilities and the market value of common equity divided by the book value of total assets. The post-euro time period is defined as years 1998-2000. The EMU-countries classified as weak (i.e., countries with a recent currency crisis) are: Finland, Italy, Ireland, Portugal and Spain. The euro exchange rate exposure is measured as the exchange rate beta from a two-factor model of stock returns in which changes in the (synthetic) euro exchange rate and the domestic stock market return are the two factors. The estimations of exchange rate betas are performed using monthly data over the time period January 1992 to December 1994. A firm is classified as having significant positive or negative euro exchange rate exposure if the exchange rate beta is significant at the 5\%-level according to a one-sided t-test. A firm is classified as large if its book value of total assets in 1995 is above the median book value of total assets among sample firms from the same country and year; otherwise it is classified as a small firm. Control variables (log of sales, EBITDA/ total assets, fixed tangible assets / total assets, current year real GDP growth, and current year domestic stock market return) and time dummies are included but not reported. T-statistics based on robust standard errors adjusted for firm dependence within country-years are reported within parentheses. *, $* *$, and $* * *$, denotes significance at the $10 \%, 5 \%$, and $1 \%$-levels, respectively.

\begin{tabular}{|c|c|c|c|c|c|c|c|c|c|c|c|c|}
\hline \multirow[b]{2}{*}{ Explanatory Variable: } & \multicolumn{4}{|c|}{ All firms } & \multicolumn{4}{|c|}{ Large firms } & \multicolumn{4}{|c|}{ Small firms } \\
\hline & (1) & (2) & (3) & (4) & (5) & (6) & (7) & (8) & (9) & $(10)$ & $(11)$ & (12) \\
\hline $\begin{array}{l}\text { EMU-country } x \\
\text { post-euro time period }\end{array}$ & $\begin{array}{l}0.054 \\
(1.60)\end{array}$ & $\begin{array}{l}0.054 \\
(1.61)\end{array}$ & & & $\begin{array}{l}0.078 * * * \\
(2.71)\end{array}$ & $\begin{array}{l}0.078 * * * \\
(2.721)\end{array}$ & & & $\begin{array}{l}0.034 \\
(0.79)\end{array}$ & $\begin{array}{l}0.034 \\
(0.79)\end{array}$ & & \\
\hline $\begin{array}{l}\text { Strong EMU-country } \mathrm{x} \\
\text { post-euro time period }\end{array}$ & & & $\begin{array}{l}0.031 \\
(0.85)\end{array}$ & $\begin{array}{c}0.031 * * \\
(0.87)\end{array}$ & & & $\begin{array}{c}0.063 * * \\
(2.06)\end{array}$ & $\begin{array}{c}0.063 * * \\
(2.07)\end{array}$ & & & $\begin{array}{l}0.002 \\
(0.04)\end{array}$ & $\begin{array}{l}0.002 \\
(0.06)\end{array}$ \\
\hline $\begin{array}{l}\text { Weak EMU-country } \mathrm{x} \\
\text { post-euro time period }\end{array}$ & & & $\begin{array}{l}0.130 * * * \\
(3.57)\end{array}$ & $\begin{array}{l}0.129 * * * \\
(3.55)\end{array}$ & & & $\begin{array}{l}0.131 * * * \\
(3.74)\end{array}$ & $\begin{array}{l}0.130 * * * \\
(3.74)\end{array}$ & & & $\begin{array}{l}0.141 * * * \\
\quad(3.04)\end{array}$ & $\begin{array}{l}0.138 * * * \\
\quad(2.98)\end{array}$ \\
\hline $\begin{array}{l}\text { EMU-country } \mathrm{x} \\
\text { post-euro time period } \mathrm{x} \\
\text { significant euro exposure }\end{array}$ & $\begin{array}{l}0.053 * * * \\
(3.51)\end{array}$ & & $\begin{array}{l}0.048 * * \\
(3.20)\end{array}$ & & $\begin{array}{l}0.053^{*} \\
(1.93)\end{array}$ & & $\begin{array}{c}0.051^{*} \\
(1.83)\end{array}$ & & $\begin{array}{l}0.046 \\
(1.59)\end{array}$ & & $\begin{array}{l}0.038 \\
(1.38)\end{array}$ & \\
\hline $\begin{array}{l}\text { EMU-country } \mathrm{x} \\
\text { post-euro time period } \mathrm{x} \\
\text { significant positive euro exposure }\end{array}$ & & $\begin{array}{l}0.013 \\
(0.63)\end{array}$ & & $\begin{array}{l}0.013 \\
(0.65)\end{array}$ & & $\begin{array}{l}0.031 \\
(1.25)\end{array}$ & & $\begin{array}{l}0.030 \\
(1.21)\end{array}$ & & $\begin{array}{l}-0.033 \\
(-0.73)\end{array}$ & & $\begin{array}{l}-0.028 \\
(-0.52)\end{array}$ \\
\hline $\begin{array}{l}\text { EMU-country } \mathrm{x} \\
\text { post-euro time period } \mathrm{x} \\
\text { significant negative euro exposure }\end{array}$ & & $\begin{array}{l}0.105^{* * * *} \\
\quad(4.16)\end{array}$ & & $\begin{array}{l}0.094 * * * \\
(3.85)\end{array}$ & & $\begin{array}{c}0.101 * * \\
(1.96)\end{array}$ & & $\begin{array}{l}0.095^{*} \\
(1.84)\end{array}$ & & $\begin{array}{l}0.107 * * * \\
\quad(3.04)\end{array}$ & & $\begin{array}{l}0.089 * * * \\
\quad(2.78)\end{array}$ \\
\hline Control variables & Yes & Yes & Yes & Yes & Yes & Yes & Yes & Yes & Yes & Yes & Yes & Yes \\
\hline Year dummies & Yes & Yes & Yes & Yes & Yes & Yes & Yes & Yes & Yes & Yes & Yes & Yes \\
\hline Adjusted $\mathrm{R}^{2}$ & 0.741 & 0.740 & 0.741 & 0.741 & 0.772 & 0.772 & 0.772 & 0.772 & 0.720 & 0.720 & 0.721 & 0.721 \\
\hline Number of firm-year observations & 9,241 & 9,241 & 9,241 & 9,241 & 4,720 & 4,720 & 4,720 & 4,720 & 4,521 & 4,521 & 4,521 & 4,521 \\
\hline
\end{tabular}


Table 5. The introduction of the euro, convergence criteria, corporate taxes, and firm value: Fixed firm-effects regression analysis

The sample covers the time period 1995-2000 and includes all firms from the EMU-countries (except Luxembourg and Greece) and five Non-EMU countries (Denmark, Norway, Sweden, Switzerland, and UK) with data available in DataStream for at least the time period 1995-1998. The dependent variable is the log of the Tobin's Q, defined as the sum of the book value of non-equity liabilities and the market value of common equity divided by the book value of total assets. The post-euro time period is defined as years 1998-2000. The EMU-countries classified as weak (i.e., countries with a recent currency crisis) are: Finland, Italy, Ireland, Portugal and Spain. A firm is classified as large if its book value of total assets in 1995 is above the median book value of total assets among sample firms from the same country and year; otherwise it is classified as a small firm. Control variables (log of sales, EBITDA/ total assets, fixed tangible assets / total assets, current year real GDP growth, and current year domestic stock market return) and time dummies are included but not reported. T-statistics based on robust standard errors adjusted for firm dependence within country-years are reported within parentheses. *, **, and ***, denotes significance at the $10 \%, 5 \%$, and $1 \%$ levels, respectively.

\begin{tabular}{|c|c|c|c|c|c|c|}
\hline \multirow[b]{2}{*}{ Explanatory Variable: } & \multicolumn{2}{|c|}{ All firms } & \multicolumn{2}{|c|}{ Large firms } & \multicolumn{2}{|c|}{ Small firms } \\
\hline & (1) & (2) & (3) & (4) & (5) & (6) \\
\hline EMU-country x post-euro time period & $\begin{array}{l}0.048 \\
(1.49)\end{array}$ & & $\begin{array}{c}0.073^{* *} \\
(2.53)\end{array}$ & & $\begin{array}{l}0.026 \\
(0.64)\end{array}$ & \\
\hline Strong EMU-country x post-euro time period & & $\begin{array}{l}0.029 \\
(0.81)\end{array}$ & & $\begin{array}{c}0.056^{*} \\
(1.85)\end{array}$ & & $\begin{array}{l}0.002 \\
(0.04)\end{array}$ \\
\hline Weak EMU-country x post-euro time period & & $\begin{array}{l}0.120 * * * \\
(3.55)\end{array}$ & & $\begin{array}{l}0.134 * * * \\
(4.26)\end{array}$ & & $\begin{array}{c}0.110 * * \\
(2.52)\end{array}$ \\
\hline $\begin{array}{l}\text { Indicator for decrease in corporate taxes in post-euro } \\
\text { time period }\end{array}$ & $\begin{array}{l}0.016 \\
(0.52)\end{array}$ & $\begin{array}{l}0.035 \\
(1.13)\end{array}$ & $\begin{array}{l}0.031 \\
(1.14)\end{array}$ & $\begin{array}{c}0.048^{*} \\
(1.86)\end{array}$ & $\begin{array}{l}0.005 \\
(0.12)\end{array}$ & $\begin{array}{l}0.026 \\
(0.64)\end{array}$ \\
\hline \multicolumn{7}{|l|}{ Convergence variables: } \\
\hline Government deficit & $\begin{array}{l}-0.074 \\
(-0.05)\end{array}$ & $\begin{array}{l}-0.128 \\
(-0.09)\end{array}$ & $\begin{array}{l}-0.808 \\
(-0.64)\end{array}$ & $\begin{array}{l}-0.854 \\
(-0.66)\end{array}$ & $\begin{array}{l}0.608 \\
(0.37)\end{array}$ & $\begin{array}{l}0.542 \\
(0.32)\end{array}$ \\
\hline Government debt / GDP & $\begin{array}{l}-0.175 \\
(-0.60)\end{array}$ & $\begin{array}{l}-0.146 \\
(-0.52)\end{array}$ & $\begin{array}{l}-0.411 \\
(-1.32)\end{array}$ & $\begin{array}{l}-0.396 \\
(-1.31)\end{array}$ & $\begin{array}{l}0.087 \\
(0.26)\end{array}$ & $\begin{array}{l}0.135 \\
(0.41)\end{array}$ \\
\hline Inflation & $\begin{array}{l}-2.877 \\
(-0.80)\end{array}$ & $\begin{array}{l}-2.245 \\
(-0.65)\end{array}$ & $\begin{array}{l}-1.287 \\
(-0.43)\end{array}$ & $\begin{array}{l}-0.792 \\
(-0.28)\end{array}$ & $\begin{array}{l}-4.748 \\
(-1.07)\end{array}$ & $\begin{array}{l}-3.938 \\
(-0.93)\end{array}$ \\
\hline Long-tern interest rate & $\begin{array}{l}-3.320 \\
(-1.12)\end{array}$ & $\begin{array}{l}-3.085 \\
(-1.19)\end{array}$ & $\begin{array}{l}-3.367 \\
(-1.31)\end{array}$ & $\begin{array}{l}-3.140 \\
(-1.40)\end{array}$ & $\begin{array}{l}-3.329 \\
(-0.92)\end{array}$ & $\begin{array}{l}-3.087 \\
(-0.95)\end{array}$ \\
\hline Control variables & Yes & Yes & Yes & Yes & Yes & Yes \\
\hline Year dummies & Yes & Yes & Yes & Yes & Yes & Yes \\
\hline Adjusted $\mathrm{R}^{2}$ & 0.736 & 0,737 & 0.766 & 0.767 & 0.718 & 0.719 \\
\hline Number of firm-year observations & 10,332 & 10,332 & 5,124 & 5,124 & 5,208 & 5,208 \\
\hline
\end{tabular}


Table 6. Takeover activity $1995-2000$

The table shows the Number and euro Value of Consummated Acquisitions of Domestic Firms, relative to the Number of Listed firms, and Total Market Capitalization in euros, respectively, by geographical region and year. The value of consummated acquisitions ( $€$ ) equals the total value of consideration paid by the acquirer, excluding fees and expenses. The euro value includes the amount paid for all common stock, common stock equivalents, preferred stock, debt, options, assets, warrants, and stake purchases made within six months of the announcement date of the transaction. Liabilities assumed are included in the value if they are publicly disclosed. Preferred stock is included only if it is being acquired as part of a $100 \%$ acquisition. If a portion of the consideration paid by the acquirer is common stock, the stock is valued by using the closing price on the last full trading day before the announcement of the terms of the stock swap. If the exchange ratio of shares offered changes, the stock is valued based on its closing price on the last full trading date before the date of the exchange ratio change. For public target $100 \%$ acquisitions, the number of shares at date of announcement is used. Data on the number of listed firms and the market capitalization in each country is obtained from the International Finance Corporation manuals. The sample includes all the acquisitions of public companies available in Securities Data Corporation, from January 1, 1995, through December 31, 2000, for the countries considered in Bris and Cabolis (2002). Only completed transactions are considered, and we exclude from the initial sample LBO deals, as well as spin-offs, recapitalizations, self-tender and exchange offers, repurchases, minority stake purchases, acquisitions of remaining interest, and privatizations.

\begin{tabular}{|c|c|c|c|c|c|c|c|c|c|}
\hline \multirow[b]{3}{*}{ Year } & \multicolumn{9}{|c|}{ Number of Acquisitions / Number of Listed Companies } \\
\hline & \multicolumn{3}{|c|}{ EMU Targets by } & \multicolumn{3}{|c|}{ Non-EMU Targets by } & \multicolumn{3}{|c|}{ Rest of the World Targets by } \\
\hline & All & $\begin{array}{l}\text { Non-EMU } \\
\text { Acquirers }\end{array}$ & $\begin{array}{l}\text { Rest of world } \\
\text { Acquirer }\end{array}$ & All & EMU Acquirers & $\begin{array}{l}\text { Rest of World } \\
\text { Acquirer }\end{array}$ & All & $\begin{array}{c}\text { EMU } \\
\text { Acquirers }\end{array}$ & $\begin{array}{l}\text { Non-EMU } \\
\text { Acquirers }\end{array}$ \\
\hline 1995 & $6.06 \%$ & $3.57 \%$ & $2.50 \%$ & $4.66 \%$ & $0.87 \%$ & $3.79 \%$ & $0.89 \%$ & $0.19 \%$ & $0.70 \%$ \\
\hline 1996 & $6.77 \%$ & $3.78 \%$ & $2.99 \%$ & $5.30 \%$ & $1.12 \%$ & $4.18 \%$ & $0.74 \%$ & $0.17 \%$ & $0.57 \%$ \\
\hline 1997 & $8.87 \%$ & $4.85 \%$ & $4.01 \%$ & $7.92 \%$ & $1.40 \%$ & $6.51 \%$ & $1.00 \%$ & $0.28 \%$ & $0.72 \%$ \\
\hline 1998 & $9.16 \%$ & $4.37 \%$ & $4.79 \%$ & $8.48 \%$ & $1.88 \%$ & $6.60 \%$ & $1.10 \%$ & $0.39 \%$ & $0.71 \%$ \\
\hline 1999 & $6.48 \%$ & $3.67 \%$ & $2.81 \%$ & $9.09 \%$ & $2.75 \%$ & $6.35 \%$ & $1.33 \%$ & $0.52 \%$ & $0.81 \%$ \\
\hline \multirow[t]{4}{*}{2000} & $6.64 \%$ & $4.40 \%$ & $2.24 \%$ & $10.10 \%$ & $4.23 \%$ & $5.87 \%$ & $1.55 \%$ & $0.69 \%$ & $0.86 \%$ \\
\hline & \multicolumn{9}{|c|}{$€$ Value of Acquisitions / Market Capitalization } \\
\hline & \multicolumn{3}{|c|}{ EMU Targets by } & \multicolumn{3}{|c|}{ Non-EMU Targets by } & \multicolumn{3}{|c|}{ Rest of the World Targets by } \\
\hline & All & $\begin{array}{l}\text { Non-EMU } \\
\text { Acquirers }\end{array}$ & $\begin{array}{l}\text { Rest of world } \\
\text { Acquirer }\end{array}$ & All & EMU Acquirers & $\begin{array}{l}\text { Rest of World } \\
\text { Acquirer }\end{array}$ & All & $\begin{array}{c}\text { EMU } \\
\text { Acquirers }\end{array}$ & $\begin{array}{l}\text { Non-EMU } \\
\text { Acquirers }\end{array}$ \\
\hline 1995 & $0.77 \%$ & $0.28 \%$ & $0.49 \%$ & $1.38 \%$ & $0.36 \%$ & $1.02 \%$ & $0.17 \%$ & $0.10 \%$ & $0.08 \%$ \\
\hline 1996 & $0.94 \%$ & $0.70 \%$ & $0.24 \%$ & $0.53 \%$ & $0.14 \%$ & $0.39 \%$ & $0.31 \%$ & $0.16 \%$ & $0.14 \%$ \\
\hline 1997 & $0.76 \%$ & $0.44 \%$ & $0.32 \%$ & $1.49 \%$ & $0.32 \%$ & $1.16 \%$ & $0.30 \%$ & $0.09 \%$ & $0.21 \%$ \\
\hline 1998 & $0.51 \%$ & $0.22 \%$ & $0.28 \%$ & $1.51 \%$ & $0.65 \%$ & $0.86 \%$ & $1.28 \%$ & $0.44 \%$ & $0.84 \%$ \\
\hline 1999 & $4.80 \%$ & $4.38 \%$ & $0.43 \%$ & $2.78 \%$ & $1.46 \%$ & $1.31 \%$ & $0.81 \%$ & $0.47 \%$ & $0.34 \%$ \\
\hline 2000 & $1.17 \%$ & $0.73 \%$ & $0.44 \%$ & $2.93 \%$ & $2.16 \%$ & $0.77 \%$ & $1.38 \%$ & $0.88 \%$ & $0.50 \%$ \\
\hline
\end{tabular}


Table 7. The introduction of the euro, cross-border takeover activity, and firm value: Fixed firm-effects regression analysis

The sample covers the time period 1995-2000 and includes all firms from the EMU-countries (except Luxembourg and Greece) and five Non-EMU countries (Denmark, Norway, Sweden, Switzerland, and UK) with data available in DataStream for at least the time period 1995-1998. The dependent variable is the log of the Tobin's Q, defined as the sum of the book value of non-equity liabilities and the market value of common equity divided by the book value of total assets.

The post-euro time period is defined as years 1998-2000. The EMU-countries classified as weak (i.e., countries with a recent currency crisis) are: Finland, Italy, Ireland, Portugal and Spain A firm is classified as large if its book value of total assets in 1995 is above the median book value of total assets among sample firms from the same country and year; otherwise it is classified as a small firm. Control variables (log of sales, EBITDA/ total assets, fixed tangible assets / total assets, current year real GDP growth, and current year domestic stock market return) and time dummies are included but not reported. T-statistics based on robust standard errors adjusted for firm dependence within country-years are reported within parentheses. *, **, and ***, denotes significance at the $10 \%, 5 \%$, and $1 \%$ levels, respectively.

\begin{tabular}{|c|c|c|c|c|c|c|}
\hline \multirow[b]{2}{*}{ Explanatory Variable: } & \multicolumn{2}{|c|}{ All firms } & \multicolumn{2}{|c|}{ Large firms } & \multicolumn{2}{|c|}{ Small firms } \\
\hline & (1) & $(2)$ & (3) & (4) & $(5)$ & $(6)$ \\
\hline EMU-country x post-euro time period & $\begin{array}{c}0.063^{*} \\
(1.90)\end{array}$ & & $\begin{array}{c}0.084 * * * \\
(2.96)\end{array}$ & & $\begin{array}{l}0.044 \\
(1.06)\end{array}$ & \\
\hline Strong EMU-country x post-euro time period & & $\begin{array}{l}0.039 \\
(1.12)\end{array}$ & & $\begin{array}{c}0.065^{* *} \\
(2.23)\end{array}$ & & $\begin{array}{l}0.014 \\
(0.32)\end{array}$ \\
\hline Weak EMU-country x post-euro time period & & $\begin{array}{l}0.145 * * * \\
(3.63)\end{array}$ & & $\begin{array}{l}0.150 * * * \\
(4.21)\end{array}$ & & $\begin{array}{l}0.145^{* * *} \\
(2.82)\end{array}$ \\
\hline $\begin{array}{l}\text { Cross-border takeover activity } \\
\quad \text { (=Domestic targets/ Number of firms in domestic market) }\end{array}$ & $\begin{array}{l}0.261 \\
(1.12)\end{array}$ & $\begin{array}{l}0.355 \\
(1.51)\end{array}$ & $\begin{array}{l}0.241 \\
(1.37)\end{array}$ & $\begin{array}{c}0.319^{*} \\
(1.70)\end{array}$ & $\begin{array}{l}0.279 \\
(0.84)\end{array}$ & $\begin{array}{l}0.390 \\
(1.19)\end{array}$ \\
\hline Control variables & Yes & Yes & Yes & Yes & Yes & Yes \\
\hline Year dummies & Yes & Yes & Yes & Yes & Yes & Yes \\
\hline Adjusted $\mathrm{R}^{2}$ & 0.735 & 0,736 & 0.766 & 0.766 & 0.717 & 0.718 \\
\hline Number of firm-year observations & 10,332 & 10,332 & 5,124 & 5,124 & 5,208 & 5,208 \\
\hline
\end{tabular}


Table 8: Median corporate investment: 1995-2000

The table displays median corporate investment over the time-period 1995-2000 for all firms from the EMUcountries (except Luxembourg and Greece) and five Non-EMU countries (Denmark, Norway, Sweden, Switzerland, and UK) with data available in DataStream for at least the time period 1995-1998. Corporate investment is defined as the change in total assets between year $t-1$ and year $t$ divided by total assets year $t-1$. The Wilcoxon rank-sum test in Panel A tests if the median corporate investment for EMU-countries is equal to the median corporate investment for Non-EMU countries for each year. All data is collected from DataStream.

Panel A: EMU vs. Non-EMU countries

\begin{tabular}{lllllll}
\hline \multicolumn{7}{c}{ Median corporate investment } \\
\hline EMU-countries & 1995 & 1996 & 1997 & 1998 & 1999 & 2000 \\
$\quad \begin{array}{l}\text { Number of firms } \\
\text { Non-EMU-countries }\end{array}$ & $3.7 \%$ & $3.4 \%$ & $3.9 \%$ & $6.2 \%$ & $4.7 \%$ & $7.6 \%$ \\
Number of firms & 757 & 757 & 757 & 757 & 719 & 662 \\
$\quad$ & $9.0 \%$ & $8.3 \%$ & $5.6 \%$ & $7.3 \%$ & $6.2 \%$ & $7.6 \%$ \\
\hline $\begin{array}{l}\text { Wilcoxon rank-sum test } \\
\text { (p-value) }\end{array}$ & 938 & 938 & 938 & 938 & 810 & 668 \\
\hline
\end{tabular}

$\underline{\text { Panel B: Individual countries }}$

\begin{tabular}{|c|c|c|c|c|c|c|}
\hline & \multicolumn{6}{|c|}{ Median corporate investment } \\
\hline & 1995 & 1996 & 1997 & 1998 & 1999 & 2000 \\
\hline \multicolumn{7}{|l|}{ EMU-countries: } \\
\hline Germany & $3.5 \%$ & $2.9 \%$ & $2.3 \%$ & $3.2 \%$ & $3.4 \%$ & $3.8 \%$ \\
\hline Number of firms & 360 & 360 & 360 & 360 & 337 & 296 \\
\hline Belgium & $2.3 \%$ & $3.2 \%$ & $6.6 \%$ & $11.3 \%$ & $6.1 \%$ & $13.2 \%$ \\
\hline Number of firms & 28 & 28 & 28 & 28 & 28 & 27 \\
\hline Spain: & $4.2 \%$ & $3.7 \%$ & $11.7 \%$ & $10.6 \%$ & $7.0 \%$ & $18.9 \%$ \\
\hline Number of firms & 40 & 40 & 40 & 40 & 39 & 39 \\
\hline Finland: & $0.7 \%$ & $2.8 \%$ & $4.6 \%$ & $10.0 \%$ & $3.6 \%$ & $8.5 \%$ \\
\hline Number of firms & 25 & 25 & 25 & 25 & 25 & 25 \\
\hline France: & $3.7 \%$ & $3.0 \%$ & $3.9 \%$ & $6.4 \%$ & $4.5 \%$ & $10.6 \%$ \\
\hline Number of firms & 144 & 144 & 144 & 144 & 136 & 133 \\
\hline Ireland: & $7.0 \%$ & $4.4 \%$ & $10.6 \%$ & $29.2 \%$ & $5.6 \%$ & $11.3 \%$ \\
\hline Number of firms & 9 & 9 & 9 & 9 & 9 & 9 \\
\hline Italy: & $3.3 \%$ & $3.1 \%$ & $-0.9 \%$ & $7.8 \%$ & $3.4 \%$ & $5.1 \%$ \\
\hline Number of firms & 33 & 33 & 33 & 33 & 32 & 32 \\
\hline Netherlands: & $5.8 \%$ & $6.7 \%$ & $11.6 \%$ & $12.5 \%$ & $9.5 \%$ & $16.6 \%$ \\
\hline Number of firms & 59 & 59 & 59 & 59 & 59 & 55 \\
\hline Austria: & $5.5 \%$ & $3.5 \%$ & $0.4 \%$ & $2.5 \%$ & $4.3 \%$ & $6.6 \%$ \\
\hline Number of firms & 25 & 25 & 25 & 25 & 24 & 24 \\
\hline Portugal: & $0.7 \%$ & $2.0 \%$ & $3.7 \%$ & $4.8 \%$ & $14.7 \%$ & $6.0 \%$ \\
\hline Number of firms & 34 & 34 & 34 & 34 & 30 & 22 \\
\hline \multicolumn{7}{|c|}{ Non-EMU-countries: } \\
\hline Denmark: & $5.1 \%$ & $4.0 \%$ & $8.5 \%$ & $5.9 \%$ & $6.2 \%$ & $7.8 \%$ \\
\hline Number of firms & 26 & 26 & 26 & 26 & 26 & 25 \\
\hline Norway: & $4.1 \%$ & $12.0 \%$ & $14.0 \%$ & $21.1 \%$ & $13.9 \%$ & $5.7 \%$ \\
\hline Number of firms & 43 & 43 & 43 & 43 & 43 & 42 \\
\hline Sweden: & $9.9 \%$ & $5.9 \%$ & $4.6 \%$ & $13.7 \%$ & $10.5 \%$ & $6.7 \%$ \\
\hline Number of firms & 64 & 64 & 64 & 64 & 62 & 54 \\
\hline Switzerland & $2.9 \%$ & $-0.9 \%$ & $8.9 \%$ & $2.1 \%$ & $4.1 \%$ & $4.7 \%$ \\
\hline Number of firms & 56 & 56 & 56 & 56 & 56 & 56 \\
\hline UK & $10.0 \%$ & $9.6 \%$ & $4.9 \%$ & $7.2 \%$ & $5.4 \%$ & $8.2 \%$ \\
\hline Number of firms & 749 & 749 & 749 & 749 & 623 & 491 \\
\hline
\end{tabular}


Table 9. The introduction of the euro and corporate investment: Fixed firm-effects regression analysis

The sample covers the time period 1995-2000 and includes all firms from the EMU-countries (except Luxembourg and Greece) and five Non-EMU countries (Denmark, Norway, Sweden, Switzerland, and UK) with data available in Datastream for at least the time period 1995-1998. The dependent variable is corporate investment, defined as the change in he book value total assets between year $t-1$ and year $t$ divided by the book value of total assets year $t-1$. To control for outliers, the dependent variable is winsorized at the $5^{\text {th }}$ and $95^{\text {th }}$ percentiles. The post-euro time period is defined as years 1998-2000. The weak EMU-countries (i.e., countries with a recent currency crisis) are: Finland, Italy, Ireland, Portugal and Spain. A firm is classified as large if its book value of total assets in 1995 is above the median book value of total assets among sample firms from the same country and year; otherwise it is classified as a small firm. T-statistics based on robust standard errors adjusted for firm dependence within country-years are reported within parentheses. *,**, and ***, denotes significance at the $10 \%, 5 \%$, and $1 \%$-levels, respectively.

\begin{tabular}{|c|c|c|c|c|c|c|}
\hline \multirow[b]{2}{*}{ Explanatory Variable: } & \multicolumn{2}{|c|}{ All firms } & \multicolumn{2}{|c|}{ Large firms } & \multicolumn{2}{|c|}{ Small firms } \\
\hline & (1) & (2) & (3) & (4) & $(5)$ & (6) \\
\hline EMU-country x post-euro time period & $\begin{array}{c}0.033 * * * \\
(3.48)\end{array}$ & & $\begin{array}{c}0.042 * * * \\
(3.56)\end{array}$ & & $\begin{array}{c}0.022 * * \\
(2.40)\end{array}$ & \\
\hline Strong EMU-country x post-euro time period & & $\begin{array}{c}0.030 * * * \\
(3.12)\end{array}$ & & $\begin{array}{c}0.038 * * * \\
(3.19)\end{array}$ & & $\begin{array}{c}0.019 * * \\
(2.06)\end{array}$ \\
\hline Weak EMU-country x post euro time period & & $\begin{array}{c}0.051 * * * \\
(2.80)\end{array}$ & & $\begin{array}{c}0.063 * * * \\
(2.87)\end{array}$ & & $\begin{array}{c}0.037 * \\
(1.90)\end{array}$ \\
\hline Lagged Tobin's Q & $\begin{array}{c}0.077 * * * \\
(13.68)\end{array}$ & $\begin{array}{c}0.077 * * * \\
(13.70)\end{array}$ & $\begin{array}{c}0.089 * * * \\
(7.60)\end{array}$ & $\begin{array}{c}0.089 * * * \\
(7.62)\end{array}$ & $\begin{array}{c}0.072 * * * \\
(12.93)\end{array}$ & $\begin{array}{c}0.072 * * \\
(12.92)\end{array}$ \\
\hline Lagged EBITDA/ total assets & $\begin{array}{c}0.220^{* * * *} \\
\quad(6.28)\end{array}$ & $\begin{array}{c}0.220 * * * \\
\quad(6.24)\end{array}$ & $\begin{array}{c}0.348^{* * * *} \\
(8.43)\end{array}$ & $\begin{array}{c}0.348^{* * * *} \\
(8.42)\end{array}$ & $\begin{array}{c}0.151^{* * * *} \\
(3.65)\end{array}$ & $\begin{array}{c}0.151 * * * \\
\quad(3.63)\end{array}$ \\
\hline Lagged real GDP growth & $\begin{array}{l}0.444 \\
(1.11)\end{array}$ & $\begin{array}{l}0.388 \\
(0.98)\end{array}$ & $\begin{array}{l}-0.053 \\
(-0.10)\end{array}$ & $\begin{array}{l}-0.127 \\
(-0.25)\end{array}$ & $\begin{array}{c}0.905 * * \\
(2.35)\end{array}$ & $\begin{array}{c}0.905 * * \\
(2.10)\end{array}$ \\
\hline Year dummies & Yes & Yes & Yes & Yes & Yes & Yes \\
\hline Adjusted $\mathrm{R}^{2}$ & 0.242 & 0.243 & 0.238 & 0.238 & 0.249 & 0.249 \\
\hline Number of firm-year observations & 9,621 & 9,621 & 5,088 & 5,088 & 4,533 & 4,533 \\
\hline
\end{tabular}


Table 10. The introduction of the euro, exchange rate exposure, and corporate investment: Fixed firm-effects regression analysis

The sample covers the time period 1995-2000 and includes all firms from the EMU-countries (except Luxembourg and Greece) and five Non-EMU countries (Denmark, Norway, Sweden, Switzerland, and UK) with data available in DataStream for at least the time period 1995-1998. The dependent variable is corporate investment, defined as the change in total assets between year $t-1$ and year $t$ divided by total assets year $t-1$. To control for outliers, the dependent variable is winsorized at the $5^{\text {th }}$ and $95^{\text {th }}$ percentiles. The post-euro time period is defined as years 1998-2000. The weak EMU-countries (i.e., countries with a recent currency crisis) are: Finland, Italy, Ireland, Portugal and Spain. The euro exchange rate exposure is measured as the exchange rate beta from a two-factor model of stock returns in which changes in the (synthetic) euro exchange rate and the domestic stock market return are the two factors. The estimations of exchange rate betas are performed using monthly data over the time period January 1992 to December 1994. A firm is classified as having significant positive or negative euro exchange rate exposure if the exchange rate beta is significant at the 5\%-level according to a one-sided t-test. A firm is classified as large if its book value of total assets in 1995 is above the median book value of total assets among sample firms from the same country and year; otherwise it is classified as a small firm. Control variables (lagged Tobin's Q, lagged EBITDA/total assets, and lagged real GDP) and time dummies are included but not reported. T-statistics based on robust standard errors adjusted for firm dependence within country-years are reported within parentheses. *, **, and ***, denotes significance at the $10 \%, 5 \%$, and $1 \%$-levels, respectively.

\begin{tabular}{|c|c|c|c|c|c|c|c|c|c|c|c|c|}
\hline \multirow[b]{2}{*}{ Explanatory Variable: } & \multicolumn{4}{|c|}{ All firms } & \multicolumn{4}{|c|}{ Large firms } & \multicolumn{4}{|c|}{ Small firms } \\
\hline & (1) & (2) & (3) & (4) & $(5)$ & (6) & (7) & (8) & (9) & $(10)$ & (11) & $(12)$ \\
\hline $\begin{array}{l}\text { EMU-country } \mathrm{x} \\
\text { post-euro time period }\end{array}$ & $\begin{array}{c}0.037 * * * \\
(3.86)\end{array}$ & $\begin{array}{c}0.037 * * * \\
(3.87)\end{array}$ & & & $\begin{array}{l}0.041^{* * *} * \\
(3.45)\end{array}$ & $\begin{array}{l}0.041 * * * \\
(3.45)\end{array}$ & & & $\begin{array}{c}0.030 * * * \\
(3.22)\end{array}$ & $\begin{array}{l}0.030 * * * \\
(3.23)\end{array}$ & & \\
\hline $\begin{array}{r}\text { Strong EMU-country } \mathrm{x} \\
\text { post-euro time period }\end{array}$ & & & $\begin{array}{c}0.034 * * * \\
(3.55)\end{array}$ & $\begin{array}{c}0.034 * * * \\
(3.55)\end{array}$ & & & $\begin{array}{c}0.037 * * * \\
(3.13)\end{array}$ & $\begin{array}{c}0.037 * * * \\
(3.13)\end{array}$ & & & $\begin{array}{l}0.028 * * * \\
(2.94)\end{array}$ & $\begin{array}{l}0.028 * * * \\
(2.94)\end{array}$ \\
\hline $\begin{array}{l}\text { Weak EMU-country } \mathrm{x} \\
\text { post euro time period }\end{array}$ & & & $\begin{array}{l}0.052^{* * * *} \\
(2.81)\end{array}$ & $\begin{array}{l}0.053 * * * \\
(2.84)\end{array}$ & & & $\begin{array}{l}0.061 * * * \\
(2.70)\end{array}$ & $\begin{array}{c}0.061 * * * \\
(2.70)\end{array}$ & & & $\begin{array}{l}0.041 * * \\
(2.08)\end{array}$ & $\begin{array}{c}0.042 * * \\
(2.11)\end{array}$ \\
\hline $\begin{array}{l}\text { EMU-country } x \\
\text { post-euro time period } x \\
\text { significant euro exposure }\end{array}$ & $\begin{array}{l}0.002 \\
(0.16)\end{array}$ & & $\begin{array}{l}0.001 \\
(0.08)\end{array}$ & & $\begin{array}{l}0.030^{*} \\
(1.75)\end{array}$ & & $\begin{array}{l}0.027 \\
(1.60)\end{array}$ & & $\begin{array}{l}-0.034 \\
(-1.30)\end{array}$ & & $\begin{array}{l}-0.035 \\
(-1.31)\end{array}$ & \\
\hline $\begin{array}{l}\text { EMU-country } \mathrm{x} \\
\text { post-euro time period } \mathrm{x} \\
\text { significant positive euro exposure }\end{array}$ & & $\begin{array}{l}0.018 \\
(0.93)\end{array}$ & & $\begin{array}{l}0.017 \\
(0.91)\end{array}$ & & $\begin{array}{l}0.036 \\
(1.45)\end{array}$ & & $\begin{array}{l}0.035 \\
(1.40)\end{array}$ & & $\begin{array}{l}-0.016 \\
(-0.72)\end{array}$ & & $\begin{array}{l}-0.016 \\
(-0.48)\end{array}$ \\
\hline $\begin{array}{l}\text { EMU-country } \mathrm{x} \\
\text { post-euro time period } \mathrm{x} \\
\text { significant negative euro exposure }\end{array}$ & & $\begin{array}{l}-0.020 \\
(0.96)\end{array}$ & & $\begin{array}{l}-0.022 \\
(-1.08)\end{array}$ & & $\begin{array}{l}0.017 \\
(0.72)\end{array}$ & & $\begin{array}{l}0.013 \\
(0.52)\end{array}$ & & $\begin{array}{l}-0.051 \\
(-1.42)\end{array}$ & & $\begin{array}{l}-0.052 \\
(-1.45)\end{array}$ \\
\hline Control variables & Yes & Yes & Yes & Yes & Yes & Yes & Yes & Yes & Yes & Yes & Yes & Yes \\
\hline Year dummies & Yes & Yes & Yes & Yes & Yes & Yes & Yes & Yes & Yes & Yes & Yes & Yes \\
\hline Adjusted $\mathrm{R}^{2}$ & 0.240 & 0.240 & 0.240 & 0.240 & 0.238 & 0.237 & 0.238 & 0.238 & 0.246 & 0.246 & 0.246 & 0.246 \\
\hline Number of firm-year observations & 9,317 & 9,317 & 9,317 & 9,317 & 4,981 & 4,981 & 4,981 & 4,981 & 4,336 & 4,336 & 4,336 & 4,336 \\
\hline
\end{tabular}


Table 11. Median net debt and equity issues: 1995-2000

The table displays the median net debt and equity issues over the time-period 1995-2000 for all firms from the EMU-countries (except Luxembourg and Greece) and five Non-EMU countries (Denmark, Norway, Sweden, Switzerland, and UK) with data available in DataStream for at least the time period 1995-1998. Net debt issues is defined as the change in the book value of non-equity liabilities between year $t-1$ and year $t$ divided by the book value of total assets year $t-1$. Net equity issues is defined as the change in book value of equity due to equity issues, stock repurchases and dividends to shareholders between year $t-1$ and year $t$ divided by total assets year $t-1$. The Wilcoxon rank-sum tests in Panel A test if median net debt and equity issues for EMU-countries are equal to median net debt and equity issues for Non-EMU countries for each year. All data is collected from DataStream

Panel A: EMU vs. Non-EMU countries

\begin{tabular}{|c|c|c|c|c|c|c|}
\hline & \multicolumn{6}{|c|}{ Median net debt and equity issues } \\
\hline & 1995 & 1996 & 1997 & 1998 & 1999 & 2000 \\
\hline \multicolumn{7}{|l|}{ EMU-countries } \\
\hline Net debt issues & $1.8 \%$ & $1.9 \%$ & $1.6 \%$ & $3.4 \%$ & $2.4 \%$ & $5.4 \%$ \\
\hline Number of firms & 757 & 757 & 757 & 757 & 719 & 662 \\
\hline Net equity issues & $0.00 \%$ & $-0.05 \%$ & $0.01 \%$ & $0.06 \%$ & $-0.08 \%$ & $0.09 \%$ \\
\hline Number of firms & 714 & 714 & 714 & 714 & 680 & 632 \\
\hline \multicolumn{7}{|l|}{ Non-EMU-countries } \\
\hline Net debt issues & $4.4 \%$ & $4.6 \%$ & $2.4 \%$ & $3.3 \%$ & $2.8 \%$ & $3.6 \%$ \\
\hline Number of firms & 938 & 938 & 938 & 938 & 810 & 668 \\
\hline Net equity issues & $0.07 \%$ & $0.06 \%$ & $0.00 \%$ & $0.00 \%$ & $0.12 \%$ & $0.26 \%$ \\
\hline Number of firms & 934 & 934 & 934 & 934 & 807 & 665 \\
\hline $\begin{array}{l}\text { Wilcoxon rank-sum test of } \\
\text { difference in change of debt } \\
\text { (p-value) }\end{array}$ & $\begin{array}{c}4.87 \\
(<0.001)\end{array}$ & $\begin{array}{c}5.27 \\
(<0.001)\end{array}$ & $\begin{array}{c}2.17 \\
(0.030)\end{array}$ & $\begin{array}{c}0.15 \\
(0.882)\end{array}$ & $\begin{array}{c}0.47 \\
(0.641)\end{array}$ & $\begin{array}{c}1.99 \\
(0.047)\end{array}$ \\
\hline $\begin{array}{l}\text { Wilcoxon rank-sum test of } \\
\text { difference in net equity issues } \\
\text { (p-value) }\end{array}$ & $\begin{array}{c}0.94 \\
(0.347)\end{array}$ & $\begin{array}{c}6.01 \\
(<0.001)\end{array}$ & $\begin{array}{c}2.37 \\
(0.018)\end{array}$ & $\begin{array}{c}2.20 \\
(<0.028)\end{array}$ & $\begin{array}{c}5.16 \\
(<0.001)\end{array}$ & $\begin{array}{c}1.70 \\
(0.089)\end{array}$ \\
\hline
\end{tabular}




\section{Table 11 (continued)}

Panel B: Individual countries

\begin{tabular}{|c|c|c|c|c|c|c|c|}
\hline & & \multicolumn{6}{|c|}{ Median net debt and equity issues } \\
\hline & & 1995 & 1996 & 1997 & 1998 & 1999 & 2000 \\
\hline \multicolumn{8}{|c|}{ EMU-countries: } \\
\hline \multirow[t]{4}{*}{ Germany: } & Net debt issues & $2.4 \%$ & $2.2 \%$ & $1.2 \%$ & $1.8 \%$ & $1.7 \%$ & $1.8 \%$ \\
\hline & Number of firms & 360 & 360 & 360 & 360 & 337 & 296 \\
\hline & Net equity issues & $0.00 \%$ & $0.00 \%$ & $0.00 \%$ & $0.00 \%$ & $-0.02 \%$ & $0.00 \%$ \\
\hline & Number of firms & 359 & 359 & 359 & 359 & 336 & 295 \\
\hline \multirow[t]{4}{*}{ Belgium: } & Net debt issues & $-0.1 \%$ & $1.8 \%$ & $2.8 \%$ & $5.9 \%$ & $1.2 \%$ & $6.8 \%$ \\
\hline & Number of firms & 28 & 28 & 28 & 28 & 28 & 27 \\
\hline & Net equity issues & $-0.25 \%$ & $-0.14 \%$ & $1.0 \%$ & $1.2 \%$ & $-0.12 \%$ & $0.77 \%$ \\
\hline & Number of firms & 28 & 28 & 28 & 28 & 28 & 27 \\
\hline \multirow[t]{4}{*}{ Spain: } & Net debt issues & $1.6 \%$ & $0.4 \%$ & $4.3 \%$ & $7.1 \%$ & $6.1 \%$ & $16.3 \%$ \\
\hline & Number of firms & 40 & 40 & 40 & 40 & 39 & 39 \\
\hline & Net equity issues & $-0.01 \%$ & $-0.07 \%$ & $4.3 \%$ & $0.02 \%$ & $-0.03 \%$ & $0.00 \%$ \\
\hline & Number of firms & 36 & 36 & 36 & 36 & 35 & 35 \\
\hline \multirow[t]{4}{*}{ Finland: } & Net debt issues & $-3.2 \%$ & $-0.2 \%$ & $-0.1 \%$ & $5.0 \%$ & $0.7 \%$ & $4.0 \%$ \\
\hline & Number of firms & 25 & 25 & 25 & 25 & 25 & 25 \\
\hline & Net equity issues & $2.3 \%$ & $-0.44 \%$ & $0.07 \%$ & $0.29 \%$ & $-0.11 \%$ & $0.18 \%$ \\
\hline & Number of firms & 25 & 25 & 25 & 25 & 25 & 25 \\
\hline \multirow[t]{4}{*}{ France: } & Net debt issues & $1.3 \%$ & $1.6 \%$ & $1.2 \%$ & $2.8 \%$ & $2.0 \%$ & $6.9 \%$ \\
\hline & Number of firms & 144 & 144 & 144 & 144 & 136 & 133 \\
\hline & Net equity issues & $0.02 \%$ & $-0.01 \%$ & $0.52 \%$ & $0.35 \%$ & $-0.04 \%$ & $0.45 \%$ \\
\hline & Number of firms & 143 & 143 & 143 & 143 & 135 & 133 \\
\hline \multirow[t]{4}{*}{ Ireland: } & Net debt issues & $4.6 \%$ & $3.7 \%$ & $10.6 \%$ & $19.5 \%$ & $10.2 \%$ & $13.7 \%$ \\
\hline & Number of firms & 9 & 9 & 9 & 9 & 9 & 9 \\
\hline & Net equity issues & $0.67 \%$ & $-0.29 \%$ & $0.85 \%$ & $2.7 \%$ & $-2.8 \%$ & $2.9 \%$ \\
\hline & Number of firms & 9 & 9 & 9 & 9 & 9 & 9 \\
\hline \multirow[t]{4}{*}{ Italy: } & Net debt issues & $1.4 \%$ & $1.2 \%$ & $-2.4 \%$ & $5.5 \%$ & $0.1 \%$ & $2.7 \%$ \\
\hline & Number of firms & 33 & 33 & 33 & 33 & 32 & 32 \\
\hline & Net equity issues & $1.4 \%$ & $-0.03 \%$ & $-0.24 \%$ & $0.23 \%$ & $0.00 \%$ & $0.24 \%$ \\
\hline & Number of firms & 32 & 32 & 32 & 32 & 31 & 31 \\
\hline \multirow[t]{4}{*}{ Netherlands: } & Net debt issues & $3.7 \%$ & $3.2 \%$ & $7.9 \%$ & $8.4 \%$ & $5.3 \%$ & $13.4 \%$ \\
\hline & Number of firms & 59 & 59 & 59 & 59 & 59 & 55 \\
\hline & Net equity issues & $-1.0 \%$ & $-1.2 \%$ & $-0.04 \%$ & $-0.25 \%$ & $-1.7 \%$ & $-0.02 \%$ \\
\hline & Number of firms & 57 & 57 & 57 & 57 & 57 & 53 \\
\hline \multirow[t]{4}{*}{ Austria: } & Net debt issues & $6.5 \%$ & $1.6 \%$ & $-1.1 \%$ & $1.8 \%$ & $1.5 \%$ & $6.4 \%$ \\
\hline & Number of firms & 25 & 25 & 25 & 25 & 24 & 24 \\
\hline & Net equity issues & $-0.18 \%$ & $-0.21 \%$ & $0.00 \%$ & $0.00 \%$ & $-0.12 \%$ & $0.00 \%$ \\
\hline & Number of firms & 25 & 25 & 25 & 25 & 24 & 24 \\
\hline \multirow[t]{4}{*}{ Portugal: } & Net debt issues & $2.7 \%$ & $1.7 \%$ & $0.8 \%$ & $6.6 \%$ & $8.8 \%$ & $8.8 \%$ \\
\hline & Number of firms & 34 & 34 & 34 & 34 & 30 & 22 \\
\hline & Net equity issues & N/A & N/A & N/A & N/A & N/A & N/A \\
\hline & Number of firms & N/A & N/A & N/A & N/A & N/A & N/A \\
\hline
\end{tabular}


Table 11 (continued)

$\underline{\text { Panel B (continued) }}$

\begin{tabular}{|c|c|c|c|c|c|c|c|}
\hline & & \multicolumn{6}{|c|}{ Median net debt and equity issues } \\
\hline & & 1995 & 1996 & 1997 & 1998 & 1999 & 2000 \\
\hline \multicolumn{8}{|c|}{ Non-EMU-countries: } \\
\hline Denmark: & $\begin{array}{l}\text { Net debt issues } \\
\text { Number of firms } \\
\text { Net equity issues } \\
\text { Number of firms }\end{array}$ & $\begin{array}{l}2.0 \% \\
26 \\
-2.9 \% \\
26\end{array}$ & $\begin{array}{l}1.3 \% \\
26 \\
-2.2 \% \\
26\end{array}$ & $\begin{array}{c}4.2 \% \\
26 \\
-1.8 \% \\
26\end{array}$ & $\begin{array}{c}2.5 \% \\
26 \\
-1.8 \% \\
26\end{array}$ & $\begin{array}{l}4.7 \% \\
26 \\
-3.3 \% \\
26\end{array}$ & $\begin{array}{l}5.6 \% \\
25 \\
-3.2 \% \\
25\end{array}$ \\
\hline Norway: & $\begin{array}{l}\text { Net debt issues } \\
\text { Number of firms } \\
\text { Net equity issues } \\
\text { Number of firms }\end{array}$ & $\begin{array}{l}2.4 \% \\
43 \\
-1.5 \% \\
42\end{array}$ & $\begin{array}{c}3.6 \% \\
43 \\
-0.9 \% \\
42\end{array}$ & $\begin{array}{c}6.3 \% \\
43 \\
-1.5 \% \\
42\end{array}$ & $\begin{array}{l}10.3 \% \\
43 \\
-1.3 \% \\
42\end{array}$ & $\begin{array}{c}10.4 \% \\
43 \\
-0.4 \% \\
42\end{array}$ & $\begin{array}{c}1.0 \% \\
42 \\
0.5 \% \\
41\end{array}$ \\
\hline Sweden: & $\begin{array}{l}\text { Net debt issues } \\
\text { Change in equity } \\
\text { Number of firms } \\
\text { Net equity issues } \\
\text { Number of firms }\end{array}$ & $\begin{array}{c}3.9 \% \\
6.5 \% \\
64 \\
-0.6 \% \\
63\end{array}$ & $\begin{array}{c}0.1 \% \\
6.6 \% \\
64 \\
-1.5 \% \\
63\end{array}$ & $\begin{array}{c}-0.9 \% \\
4.3 \% \\
64 \\
-2.0 \% \\
63\end{array}$ & $\begin{array}{c}6.7 \% \\
5.9 \% \\
64 \\
-2.1 \% \\
63\end{array}$ & $\begin{array}{c}6.3 \% \\
4.8 \% \\
62 \\
-1.6 \% \\
61\end{array}$ & $\begin{array}{c}3.2 \% \\
3.5 \% \\
54 \\
-2.6 \% \\
53\end{array}$ \\
\hline Switzerland & $\begin{array}{l}\text { Net debt issues } \\
\text { Number of firms } \\
\text { Net equity issues } \\
\text { Number of firms }\end{array}$ & $\begin{array}{c}1.8 \% \\
56 \\
-2.7 \% \\
56\end{array}$ & $\begin{array}{l}-1.5 \% \\
56 \\
-2.1 \% \\
56\end{array}$ & $\begin{array}{c}3.4 \% \\
56 \\
-0.9 \% \\
56\end{array}$ & $\begin{array}{c}-0.5 \% \\
56 \\
-1.8 \% \\
56\end{array}$ & $\begin{array}{l}1.5 \% \\
56 \\
-2.2 \% \\
56\end{array}$ & $\begin{array}{c}1.0 \% \\
56 \\
-1.1 \% \\
56\end{array}$ \\
\hline UK & $\begin{array}{l}\text { Net debt issues } \\
\text { Number of firms } \\
\text { Net equity issues } \\
\text { Number of firms }\end{array}$ & $\begin{array}{c}5.3 \% \\
749 \\
-2.5 \% \\
746\end{array}$ & $\begin{array}{c}5.8 \% \\
749 \\
-2.5 \% \\
746\end{array}$ & $\begin{array}{c}2.1 \% \\
749 \\
-3.0 \% \\
746\end{array}$ & $\begin{array}{l}3.2 \% \\
749 \\
-2.9 \% \\
746\end{array}$ & $\begin{array}{c}2.5 \% \\
623 \\
-2.5 \% \\
621\end{array}$ & $\begin{array}{c}4.2 \% \\
491 \\
-1.9 \% \\
488\end{array}$ \\
\hline
\end{tabular}


Table 12. The introduction of the euro and debt and equity issues: Fixed firm-effects regression analysis

The sample covers the time period 1995-2000 and includes all firms from the EMU-countries (except Luxembourg and Greece) and five Non-EMU countries (Denmark, Norway, Sweden, Switzerland, and UK) with data available in DataStream for at least the time period 1995-1998. In Panel A, the dependent variable is net debt issues, defined as the change in the book value of non-equity liabilities between year $t-1$ and year $t$ divided by total assets year $t-1$. In Panel B, the dependent variable is net equity issues, defined as the change in book value of equity due to equity issues, stock repurchases and dividends to shareholders between year $t-1$ and year $t$ divided by total assets year $t-1$. To control for outliers, both dependent variables are winsorized at the $5^{\text {th }}$ and $95^{\text {th }}$ percentiles. The post-euro time period is defined as years 1998-2000. The weak EMU-countries (i.e., countries with a recent currency crisis) are: Finland, Italy, Ireland, Portugal and Spain. A firm is classified as large if its book value of total assets in 1995 is above the median book value of total assets among sample firms from the same country and year; otherwise it is classified as a small firm. T-statistics based on robust standard errors adjusted for firm dependence within country-years are reported within parentheses. $*{ }^{* *}$, and $* * *$, denotes significance at the $10 \%, 5 \%$, and $1 \%$-levels, respectively.

Panel A: Net debt issues

\begin{tabular}{|c|c|c|c|c|c|c|}
\hline \multirow[b]{2}{*}{ Explanatory Variable: } & \multicolumn{2}{|c|}{ All firms } & \multicolumn{2}{|c|}{ Large firms } & \multicolumn{2}{|c|}{ Small firms } \\
\hline & (1) & (2) & (3) & (4) & (5) & (6) \\
\hline EMU-country x post-euro time period & $\begin{array}{c}0.028 * * * \\
(3.03)\end{array}$ & & $\begin{array}{c}0.028 * * \\
(2.48)\end{array}$ & & $\begin{array}{c}0.026 * * * \\
(2.85)\end{array}$ & \\
\hline Strong EMU-country x post-euro time period & & $\begin{array}{c}0.024 * * * \\
(2.71)\end{array}$ & & $\begin{array}{c}0.025^{* *} \\
(2.28)\end{array}$ & & $\begin{array}{c}0.022 * * \\
(2.33)\end{array}$ \\
\hline Weak EMU-country x post euro time period & & $\begin{array}{c}0.052 * * * \\
(3.31)\end{array}$ & & $\begin{array}{c}0.049 * * \\
(2.37)\end{array}$ & & $\begin{array}{c}0.055^{* * * *} \\
(3.35)\end{array}$ \\
\hline Lagged debt/ total assets & $\begin{array}{c}-0.641 * * * \\
(-9.35)\end{array}$ & $\begin{array}{c}-0.640 * * * \\
(-9.35)\end{array}$ & $\begin{array}{c}-0.712 * * * \\
(-8.18)\end{array}$ & $\begin{array}{c}-0.710 * * * \\
(-8.17)\end{array}$ & $\begin{array}{c}-0.603 * * * \\
(-8.98)\end{array}$ & $\begin{array}{c}-0.602 * * * \\
(-8.98)\end{array}$ \\
\hline Log of current sales & $\begin{array}{c}0.029 * * * \\
(3.06)\end{array}$ & $\begin{array}{c}0.028 * * * \\
(3.00)\end{array}$ & $\begin{array}{c}0.047 * * * \\
(3.62)\end{array}$ & $\begin{array}{c}0.046 * * * \\
(3.53)\end{array}$ & $\begin{array}{c}0.018^{*} \\
(1.83)\end{array}$ & $\begin{array}{c}0.018^{*} \\
(1.80)\end{array}$ \\
\hline Lagged Tobin's Q & $\begin{array}{c}0.041 * * * \\
(11.72)\end{array}$ & $\begin{array}{c}0.041 * * * \\
(11.77)\end{array}$ & $\begin{array}{c}0.054 * * * \\
(6.89)\end{array}$ & $\begin{array}{c}0.054 * * * * \\
(6.92)\end{array}$ & $\begin{array}{c}0.036 * * * * \\
(10.47)\end{array}$ & $\begin{array}{c}0.036 * * * \\
(10.50)\end{array}$ \\
\hline Lagged EBITDA/ total assets & $\begin{array}{l}0.048 \\
(1.07)\end{array}$ & $\begin{array}{l}0.048 \\
(1.08)\end{array}$ & $\begin{array}{c}0.109 * \\
(1.70)\end{array}$ & $\begin{array}{c}0.110^{*} \\
(1.73)\end{array}$ & $\begin{array}{l}0.006 \\
(0.16)\end{array}$ & $\begin{array}{l}0.006 \\
(0.14)\end{array}$ \\
\hline Lagged fixed tangible assets / total assets & $\begin{array}{l}0.038 \\
(0.99)\end{array}$ & $\begin{array}{l}0.037 \\
(0.97)\end{array}$ & $\begin{array}{l}0.042 \\
(0.92)\end{array}$ & $\begin{array}{l}0.040 \\
(0.87)\end{array}$ & $\begin{array}{l}0.025 \\
(0.54)\end{array}$ & $\begin{array}{l}0.025 \\
(0.54)\end{array}$ \\
\hline Lagged real GDP growth & $\begin{array}{l}0.374 \\
(1.29)\end{array}$ & $\begin{array}{l}0.303 \\
(1.06)\end{array}$ & $\begin{array}{l}-0.244 \\
(-0.64)\end{array}$ & $\begin{array}{l}-0.318 \\
(-0.82)\end{array}$ & $\begin{array}{c}0.975 * * * \\
(3.14)\end{array}$ & $\begin{array}{c}0.914 * * * \\
(3.07)\end{array}$ \\
\hline Lagged domestic stock market return & $\begin{array}{l}-0.027 \\
(-1.45)\end{array}$ & $\begin{array}{c}-0.033^{*} \\
(-1.79)\end{array}$ & $\begin{array}{l}-0.028 \\
(-1.26)\end{array}$ & $\begin{array}{l}-0.034 \\
(-1.51)\end{array}$ & $\begin{array}{l}-0.028 \\
(-1.24)\end{array}$ & $\begin{array}{l}-0.033 \\
(-1.51)\end{array}$ \\
\hline Year dummies & Yes & Yes & Yes & Yes & Yes & Yes \\
\hline Adjusted $\mathrm{R}^{2}$ & 0.236 & 0.236 & 0.259 & 0.260 & 0.222 & 0.223 \\
\hline Number of firm-year observations & 8,739 & 8,739 & 4,607 & 4,607 & 4,132 & 4,132 \\
\hline
\end{tabular}


Table 12 (continued)

$\underline{\text { Panel B: Net equity issues }}$

\begin{tabular}{|c|c|c|c|c|c|c|}
\hline \multirow[b]{2}{*}{ Explanatory Variable: } & \multicolumn{2}{|c|}{ All firms } & \multicolumn{2}{|c|}{ Large firms } & \multicolumn{2}{|c|}{ Small firms } \\
\hline & (1) & (2) & (3) & (4) & $(5)$ & (6) \\
\hline EMU-country x post-euro time period & $\begin{array}{l}0.001 \\
(0.50)\end{array}$ & & $\begin{array}{l}0.005 \\
(1.02)\end{array}$ & & $\begin{array}{l}-0.004 \\
(-1.01)\end{array}$ & \\
\hline Strong EMU-country x post-euro time period & & $\begin{array}{l}0.001 \\
(0.41)\end{array}$ & & $\begin{array}{l}0.006 \\
(1.26)\end{array}$ & & $\begin{array}{l}-0.003 \\
(-0.82)\end{array}$ \\
\hline Weak EMU-country x post euro time period & $\begin{array}{l}0.001 \\
(0.17)\end{array}$ & $\begin{array}{l}-0.008 \\
(-0.75)\end{array}$ & & $\begin{array}{l}-0.004 \\
(-0.32)\end{array}$ & & $\begin{array}{l}-0.013 \\
(-1.26)\end{array}$ \\
\hline Lagged debt/ total assets & $\begin{array}{c}0.188^{* * * *} \\
(8.73)\end{array}$ & $\begin{array}{c}0.187 * * * \\
(8.72)\end{array}$ & $\begin{array}{c}0.203 * * * \\
(5.68)\end{array}$ & $\begin{array}{c}0.202 * * * \\
(5.66)\end{array}$ & $\begin{array}{c}0.182 * * * \\
(8.91)\end{array}$ & $\begin{array}{c}0.181 * * * \\
(8.89)\end{array}$ \\
\hline Log of current sales & $\begin{array}{c}-0.007 * * * \\
(-2.51)\end{array}$ & $\begin{array}{c}-0.007 * * \\
(-2.46)\end{array}$ & $\begin{array}{c}-0.013 * * * \\
(-2.86)\end{array}$ & $\begin{array}{c}-0.012 * * * \\
(-2.80)\end{array}$ & $\begin{array}{l}-0.004 \\
(-1.54)\end{array}$ & $\begin{array}{l}-0.004 \\
(-1.50)\end{array}$ \\
\hline Lagged Tobin's Q & $\begin{array}{c}0.016^{* * * *} \\
(11.07)\end{array}$ & $\begin{array}{c}0.016 * * * \\
(11.03)\end{array}$ & $\begin{array}{c}0.017 * * * \\
(4.99)\end{array}$ & $\begin{array}{c}0.017 * * * \\
(4.98)\end{array}$ & $\begin{array}{c}0.015 * * * \\
(11.39)\end{array}$ & $\begin{array}{c}0.015 * * * \\
(11.37)\end{array}$ \\
\hline Lagged EBITDA/ total assets & $\begin{array}{l}0.018 \\
(0.80)\end{array}$ & $\begin{array}{l}0.018 \\
(0.80)\end{array}$ & $\begin{array}{l}0.022 \\
(0.66)\end{array}$ & $\begin{array}{l}0.022 \\
(0.65)\end{array}$ & $\begin{array}{l}0.015 \\
(0.80)\end{array}$ & $\begin{array}{l}0.015 \\
(0.81)\end{array}$ \\
\hline Lagged Fixed tangible assets / total assets & $\begin{array}{l}-0.016 \\
(-0.95)\end{array}$ & $\begin{array}{l}-0.016 \\
(-0.92)\end{array}$ & $\begin{array}{l}-0.015 \\
(-0.74)\end{array}$ & $\begin{array}{l}-0.014 \\
(-0.68)\end{array}$ & $\begin{array}{l}-0.015 \\
(-0.65)\end{array}$ & $\begin{array}{l}-0.014 \\
(-0.64)\end{array}$ \\
\hline Lagged real GDP growth & $\begin{array}{c}-0.290 * * \\
(-2.51)\end{array}$ & $\begin{array}{c}-0.272 * * \\
(-2.26)\end{array}$ & $\begin{array}{l}-0.208 \\
(-1.38)\end{array}$ & $\begin{array}{l}-0.180 \\
(-1.15)\end{array}$ & $\begin{array}{c}-0.380 * * * \\
(-2.99)\end{array}$ & $\begin{array}{c}-0.369 * * * \\
(-2.85)\end{array}$ \\
\hline Lagged domestic stock market return & $\begin{array}{l}0.004 \\
(0.62)\end{array}$ & $\begin{array}{l}0.006 \\
(0.82)\end{array}$ & $\begin{array}{l}0.004 \\
(0.60)\end{array}$ & $\begin{array}{l}0.007 \\
(0.81)\end{array}$ & $\begin{array}{l}0.002 \\
(0.24)\end{array}$ & $\begin{array}{l}0.004 \\
(0.40)\end{array}$ \\
\hline Year dummies & Yes & Yes & Yes & Yes & Yes & Yes \\
\hline Adjusted $\mathrm{R}^{2}$ & 0.204 & 0.204 & 0.139 & 0.139 & 0.252 & 0.252 \\
\hline Number of firm-year observations & 8,534 & 8,534 & 4,497 & 4,497 & 4,037 & 4,037 \\
\hline
\end{tabular}


Table 13: Median leverage: 1995-2000

The table displays median leverage over the time-period 1995-2000 for all firms from the EMU-countries (except Luxembourg and Greece) and five Non-EMU countries (Denmark, Norway, Sweden, Switzerland, and UK) with data available in DataStream for at least the time period 1995-1998. Leverage is defined as the book value of nonequity liabilities divided by the book value of assets. All data is collected from DataStream

Panel A: EMU vs. Non-EMU countries

\begin{tabular}{|c|c|c|c|c|c|c|}
\hline & \multicolumn{6}{|c|}{ Median leverage } \\
\hline & 1995 & 1996 & 1997 & 1998 & 1999 & 2000 \\
\hline EMU-countries & $66.6 \%$ & $66.7 \%$ & $65.8 \%$ & $66.3 \%$ & $66.3 \%$ & $67.2 \%$ \\
\hline Number of firms & 757 & 757 & 757 & 757 & 719 & 662 \\
\hline Non-EMU-countries & $55.6 \%$ & $55.5 \%$ & $55.0 \%$ & $54.7 \%$ & $56.5 \%$ & $57.4 \%$ \\
\hline Number of firms & 938 & 938 & 938 & 938 & 810 & 668 \\
\hline $\begin{array}{l}\text { Wilcoxon rank-sum test } \\
\text { (p-value) }\end{array}$ & $\begin{array}{c}11.49 \\
(<0.001)\end{array}$ & $\begin{array}{c}11.85 \\
(<0.001)\end{array}$ & $\begin{array}{c}11.41 \\
(<0.001)\end{array}$ & $\begin{array}{c}11.49 \\
(<0.001)\end{array}$ & $\begin{array}{c}9.55 \\
(<0.001)\end{array}$ & $\begin{array}{c}8.64 \\
(<0.001)\end{array}$ \\
\hline
\end{tabular}

Panel B: Individual countries

\begin{tabular}{|c|c|c|c|c|c|c|}
\hline & \multicolumn{6}{|c|}{ Median leverage } \\
\hline & 1995 & 1996 & 1997 & 1998 & 1999 & 2000 \\
\hline \multicolumn{7}{|l|}{ EMU-countries: } \\
\hline $\begin{array}{l}\text { Germany } \\
\text { Number of firms }\end{array}$ & $\begin{array}{c}70.4 \% \\
360\end{array}$ & $\begin{array}{c}70.8 \% \\
360\end{array}$ & $\begin{array}{c}70.8 \% \\
360\end{array}$ & $\begin{array}{c}70.8 \% \\
360\end{array}$ & $\begin{array}{c}70.2 \% \\
337\end{array}$ & $\begin{array}{c}69.8 \% \\
296\end{array}$ \\
\hline $\begin{array}{l}\text { Belgium } \\
\text { Number of firms }\end{array}$ & $\begin{array}{c}63.1 \% \\
28\end{array}$ & $\begin{array}{c}62.9 \% \\
28\end{array}$ & $\begin{array}{c}61.9 \% \\
28\end{array}$ & $\begin{array}{c}61.6 \% \\
28\end{array}$ & $\begin{array}{c}59.6 \% \\
28\end{array}$ & $\begin{array}{c}65.3 \% \\
27\end{array}$ \\
\hline $\begin{array}{l}\text { Spain: } \\
\text { Number of firms }\end{array}$ & $\begin{array}{c}63.1 \% \\
40\end{array}$ & $\begin{array}{c}62.9 \% \\
40\end{array}$ & $\begin{array}{c}61.9 \% \\
40\end{array}$ & $\begin{array}{c}61.6 \% \\
40\end{array}$ & $\begin{array}{c}59.6 \% \\
39\end{array}$ & $\begin{array}{c}65.3 \% \\
39\end{array}$ \\
\hline $\begin{array}{l}\text { Finland: } \\
\text { Number of firms }\end{array}$ & $\begin{array}{c}61.5 \% \\
25\end{array}$ & $\begin{array}{l}62.0 \% \\
25\end{array}$ & $\begin{array}{l}59.6 \% \\
25\end{array}$ & $\begin{array}{l}58.8 \% \\
25\end{array}$ & $\begin{array}{l}59.5 \% \\
25\end{array}$ & $\begin{array}{c}61.3 \% \\
25\end{array}$ \\
\hline $\begin{array}{l}\text { France: } \\
\text { Number of firms }\end{array}$ & $\begin{array}{c}63.0 \% \\
144\end{array}$ & $\begin{array}{c}62.7 \% \\
144\end{array}$ & $\begin{array}{c}60.9 \% \\
144\end{array}$ & $\begin{array}{c}63.5 \% \\
144\end{array}$ & $\begin{array}{c}63.9 \% \\
136\end{array}$ & $\begin{array}{c}66.3 \% \\
133\end{array}$ \\
\hline $\begin{array}{l}\text { Ireland: } \\
\text { Number of firms }\end{array}$ & $\begin{array}{l}56.2 \% \\
9\end{array}$ & $\begin{array}{c}57.9 \% \\
9\end{array}$ & $\begin{array}{l}58.6 \% \\
9\end{array}$ & $\begin{array}{c}59.7 \% \\
9\end{array}$ & $\begin{array}{c}70.3 \% \\
9\end{array}$ & $\begin{array}{c}74.2 \% \\
9\end{array}$ \\
\hline $\begin{array}{l}\text { Italy: } \\
\text { Number of firms }\end{array}$ & $\begin{array}{c}56.2 \% \\
33\end{array}$ & $\begin{array}{c}57.9 \% \\
33\end{array}$ & $\begin{array}{c}58.6 \% \\
33\end{array}$ & $\begin{array}{c}59.7 \% \\
33\end{array}$ & $\begin{array}{c}70.3 \% \\
32\end{array}$ & $\begin{array}{c}74.2 \% \\
32\end{array}$ \\
\hline $\begin{array}{l}\text { Netherlands: } \\
\text { Number of firms }\end{array}$ & $\begin{array}{c}66.7 \% \\
59\end{array}$ & $\begin{array}{c}66.9 \% \\
59\end{array}$ & $\begin{array}{c}67.9 \% \\
59\end{array}$ & $\begin{array}{c}68.2 \% \\
59\end{array}$ & $\begin{array}{c}67.2 \% \\
59\end{array}$ & $\begin{array}{c}69.0 \% \\
55\end{array}$ \\
\hline $\begin{array}{l}\text { Austria: } \\
\text { Number of firms }\end{array}$ & $\begin{array}{c}66.7 \% \\
25\end{array}$ & $\begin{array}{c}71.0 \% \\
25\end{array}$ & $\begin{array}{c}69.6 \% \\
25\end{array}$ & $\begin{array}{c}70.8 \% \\
25\end{array}$ & $\begin{array}{c}70.3 \% \\
24\end{array}$ & $\begin{array}{c}67.8 \% \\
24\end{array}$ \\
\hline $\begin{array}{l}\text { Portugal: } \\
\text { Number of firms }\end{array}$ & $\begin{array}{c}57.2 \% \\
34\end{array}$ & $\begin{array}{c}56.2 \% \\
34\end{array}$ & $\begin{array}{c}55.9 \% \\
34\end{array}$ & $\begin{array}{c}56.5 \% \\
34\end{array}$ & $\begin{array}{c}61.2 \% \\
30\end{array}$ & $\begin{array}{c}64.3 \% \\
22\end{array}$ \\
\hline \multicolumn{7}{|c|}{ Non-EMU-countries: } \\
\hline $\begin{array}{l}\text { Denmark: } \\
\text { Number of firms }\end{array}$ & $\begin{array}{c}57.4 \% \\
26\end{array}$ & $\begin{array}{c}55.8 \% \\
26\end{array}$ & $\begin{array}{c}57.5 \% \\
26\end{array}$ & $\begin{array}{c}58.3 \% \\
26\end{array}$ & $\begin{array}{c}59.4 \% \\
26\end{array}$ & $\begin{array}{l}59.9 \% \\
25\end{array}$ \\
\hline $\begin{array}{l}\text { Norway: } \\
\text { Number of firms }\end{array}$ & $\begin{array}{c}60.5 \% \\
43\end{array}$ & $\begin{array}{c}58.0 \% \\
43\end{array}$ & $\begin{array}{c}57.2 \% \\
43\end{array}$ & $\begin{array}{c}56.2 \% \\
43\end{array}$ & $\begin{array}{c}64.3 \% \\
43\end{array}$ & $\begin{array}{c}61.0 \% \\
42\end{array}$ \\
\hline $\begin{array}{l}\text { Sweden: } \\
\text { Number of firms }\end{array}$ & $\begin{array}{c}60.2 \% \\
64\end{array}$ & $\begin{array}{c}56.4 \% \\
64\end{array}$ & $\begin{array}{c}55.7 \% \\
64\end{array}$ & $\begin{array}{c}56.8 \% \\
64\end{array}$ & $\begin{array}{c}58.0 \% \\
62\end{array}$ & $\begin{array}{c}58.8 \% \\
54\end{array}$ \\
\hline $\begin{array}{l}\text { Switzerland } \\
\text { Number of firms }\end{array}$ & $\begin{array}{c}62.9 \% \\
56\end{array}$ & $\begin{array}{c}62.7 \% \\
56\end{array}$ & $\begin{array}{c}61.2 \% \\
56\end{array}$ & $\begin{array}{c}61.7 \% \\
56\end{array}$ & $\begin{array}{c}63.1 \% \\
56\end{array}$ & $\begin{array}{c}60.7 \% \\
56\end{array}$ \\
\hline $\begin{array}{l}\text { UK } \\
\text { Number of firms }\end{array}$ & $\begin{array}{l}53.7 \% \\
749\end{array}$ & $\begin{array}{c}54.5 \% \\
749\end{array}$ & $\begin{array}{l}53.8 \% \\
749\end{array}$ & $\begin{array}{l}53.7 \% \\
749\end{array}$ & $\begin{array}{c}54.9 \% \\
623\end{array}$ & $\begin{array}{c}55.8 \% \\
491\end{array}$ \\
\hline
\end{tabular}


Table 14. The introduction of the euro, exchange rate exposure, and changes in debt and equity: Fixed firm-effects regression analysis

The sample covers the time period 1995-2000 and includes all firms from the EMU-countries (except Luxembourg and Greece) and five Non-EMU countries (Denmark, Norway, Sweden, Switzerland, and UK) with data available in DataStream for at least the time period 1995-1998. . In Panel A, the dependent variable is net debt issues, defined as the change in the book value of non-equity liabilities between year $t-1$ and year $t$ divided by total assets year $t-1$. In Panel $\mathrm{B}$, the dependent variable is net equity issues, defined as the change in book value of equity due to equity issues, stock repurchases and dividends to shareholders between year $t-1$ and year $t$ divided by total assets year $t-1$. To control for outliers, both dependent variables are winsorized at the $5^{\text {th }}$ and $95^{\text {th }}$ percentiles. The post-euro time period is defined as years 1998-2000. The weak EMU-countries (i.e., countries with a recent currency crisis) are: Finland, Italy, Ireland, Portugal and Spain. The euro exchange rate exposure is measured as the exchange rate beta from a two-factor model of stock returns in which changes in the (synthetic) euro exchange rate and the domestic stock market return are the two factors. The estimations of exchange rate betas are performed using monthly data over the time period January 1992 to December 1994. A firm is classified as having significant positive or negative euro exchange rate exposure if the exchange rate beta is significant at the 5\%-level according to a one-sided t-test. A firm is classified as large if its book value of total assets in 1995 is above the median book value of total assets among sample firms from the same country and year; otherwise it is classified as a small firm. Control variables (lagged debt/assets, log of sales, lagged Tobin's Q, lagged EBITDA/total assets, lagged real GDP, and lagged domestic stock market return) and time dummies are included but not reported. Tstatistics based on robust standard errors adjusted for firm dependence within country-years are reported within parentheses.*,**, and $* * *$, denotes significance at the $10 \%, 5 \%$, and $1 \%$-levels, respectively.

Panel A: Net debt issues

\begin{tabular}{|c|c|c|c|c|c|c|c|c|c|c|c|c|}
\hline \multirow[b]{2}{*}{ Explanatory Variable: } & \multicolumn{4}{|c|}{ All firms } & \multicolumn{4}{|c|}{ Large firms } & \multicolumn{4}{|c|}{ Small firms } \\
\hline & $(1)$ & $(2)$ & (3) & (4) & $(5)$ & $(6)$ & (7) & (8) & (9) & $(10)$ & (11) & (12) \\
\hline $\begin{array}{l}\text { EMU-country x } \\
\text { post-euro time period }\end{array}$ & $\begin{array}{l}0.029 * * * \\
(3.17)\end{array}$ & $\begin{array}{l}0.029 * * * \\
(3.17)\end{array}$ & & & $\begin{array}{c}0.026 * * \\
(2.33)\end{array}$ & $\begin{array}{l}0.026 * * \\
(2.34)\end{array}$ & & & $\begin{array}{l}0.032 * * * \\
(3.50)\end{array}$ & $\begin{array}{l}0.032^{* * * *} \\
(3.50)\end{array}$ & & \\
\hline $\begin{array}{l}\text { Strong EMU-country } \mathrm{x} \\
\text { post-euro time period }\end{array}$ & & & $\begin{array}{l}0.026 * * * \\
(2.86)\end{array}$ & $\begin{array}{c}0.026 * * * \\
(2.85)\end{array}$ & & & $\begin{array}{c}0.023 * * \\
(2.11)\end{array}$ & $\begin{array}{c}0.023 * * \\
(2.11)\end{array}$ & & & $\begin{array}{c}0.028 * * * \\
(3.01)\end{array}$ & $\begin{array}{c}0.028 * * * \\
(3.03)\end{array}$ \\
\hline $\begin{array}{l}\text { Weak EMU-country } \mathrm{x} \\
\text { post euro time period }\end{array}$ & & & $\begin{array}{l}0.052 * * * \\
(3.18)\end{array}$ & $\begin{array}{l}0.052 * * * \\
(3.23)\end{array}$ & & & $\begin{array}{c}0.047 * * \\
(2.25)\end{array}$ & $\begin{array}{c}0.048 * * * \\
(2.30)\end{array}$ & & & $\begin{array}{l}0.057 * * * \\
(3.46)\end{array}$ & $\begin{array}{c}0.057 * * * * \\
(3.39)\end{array}$ \\
\hline $\begin{array}{l}\text { EMU-country } \mathrm{x} \\
\text { post-euro time period } \mathrm{x} \\
\text { significant euro exposure }\end{array}$ & $\begin{array}{l}0.006 \\
(0.53)\end{array}$ & & $\begin{array}{l}0.005 \\
(0.46)\end{array}$ & & $\begin{array}{l}0.022 \\
(1.60)\end{array}$ & & $\begin{array}{l}0.021 \\
(1.52)\end{array}$ & & $\begin{array}{l}-0.016 \\
(-0.89)\end{array}$ & & $\begin{array}{l}-0.016 \\
(-0.90)\end{array}$ & \\
\hline $\begin{array}{l}\text { EMU-country } \mathrm{x} \\
\text { post-euro time period } \mathrm{x} \\
\text { significant positive euro exposure }\end{array}$ & & $\begin{array}{l}0.020 \\
(1.27)\end{array}$ & & $\begin{array}{l}0.020 \\
(1.30)\end{array}$ & & $\begin{array}{c}0.043^{* *} \\
(2.11)\end{array}$ & & $\begin{array}{l}0.043 * * \\
(2.09)\end{array}$ & & $\begin{array}{l}-0.027 \\
(-1.44)\end{array}$ & & $\begin{array}{l}-0.024 \\
(-1.28)\end{array}$ \\
\hline $\begin{array}{l}\text { EMU-country } \mathrm{x} \\
\text { post-euro time period } \mathrm{x} \\
\text { significant negative euro exposure }\end{array}$ & & $\begin{array}{l}-0.014 \\
(-0.94)\end{array}$ & & $\begin{array}{l}-0.017 \\
(-1.08)\end{array}$ & & $\begin{array}{l}-0.026 \\
(-1.56)\end{array}$ & & $\begin{array}{l}-0.028^{*} \\
(-1.69)\end{array}$ & & $\begin{array}{l}-0.006 \\
(-0.24)\end{array}$ & & $\begin{array}{l}-0.008 \\
(-0.34)\end{array}$ \\
\hline Control variables & Yes & Yes & Yes & Yes & Yes & Yes & Yes & Yes & Yes & Yes & Yes & Yes \\
\hline Year dummies & Yes & Yes & Yes & Yes & Yes & Yes & Yes & Yes & Yes & Yes & Yes & Yes \\
\hline Adjusted $\mathrm{R}^{2}$ & 0.237 & 0.237 & 0.237 & 0.237 & 0.256 & 0.257 & 0.256 & 0.257 & 0.226 & 0.226 & 0.227 & 0.227 \\
\hline Number of firm-year observations & 8,453 & 8,453 & 8,453 & 8,453 & 4,518 & 4,518 & 4,518 & 4,518 & 3,935 & 3,935 & 3,935 & 3,935 \\
\hline
\end{tabular}


Table 13 (continued).

Panel B: Net equity issues

\begin{tabular}{|c|c|c|c|c|c|c|c|c|c|c|c|c|}
\hline \multirow[b]{2}{*}{ Explanatory Variable: } & \multicolumn{4}{|c|}{ All firms } & \multicolumn{4}{|c|}{ Large firms } & \multicolumn{4}{|c|}{ Small firms } \\
\hline & (1) & $(2)$ & (3) & (4) & (5) & (6) & $(7)$ & (8) & (9) & $(10)$ & $(11)$ & (12) \\
\hline $\begin{array}{l}\text { EMU-country } x \\
\text { post-euro time period }\end{array}$ & $\begin{array}{l}0.001 \\
(0.18)\end{array}$ & $\begin{array}{l}0.001 \\
(0.18)\end{array}$ & & & $\begin{array}{l}0.005 \\
(1.08)\end{array}$ & $\begin{array}{l}0.005 \\
(1.08)\end{array}$ & & & $\begin{array}{l}-0.004 \\
(-0.98)\end{array}$ & $\begin{array}{l}-0.004 \\
(-0.99)\end{array}$ & & \\
\hline $\begin{array}{r}\text { Strong EMU-country } \mathrm{x} \\
\text { post-euro time period }\end{array}$ & & & $\begin{array}{l}0.002 \\
(0.46)\end{array}$ & $\begin{array}{l}0.002 \\
(0.44)\end{array}$ & & & $\begin{array}{l}0.006 \\
(1.37)\end{array}$ & $\begin{array}{l}0.006 \\
(1.37)\end{array}$ & & & $\begin{array}{l}-0.003 \\
(-0.78)\end{array}$ & $\begin{array}{l}-0.004 \\
(-0.82)\end{array}$ \\
\hline $\begin{array}{l}\text { Weak EMU-country } \mathrm{x} \\
\text { post euro time period }\end{array}$ & & & $\begin{array}{l}-0.009 \\
(-0.88)\end{array}$ & $\begin{array}{l}-0.009 \\
(-0.82)\end{array}$ & & & $\begin{array}{l}-0.005 \\
(-0.41)\end{array}$ & $\begin{array}{l}-0.005 \\
(-0.41)\end{array}$ & & & $\begin{array}{l}-0.015 \\
(-1.48)\end{array}$ & $\begin{array}{l}-0.014 \\
(-1.35)\end{array}$ \\
\hline $\begin{array}{l}\text { EMU-country } x \\
\text { post-euro time period } x \\
\text { significant euro exposure }\end{array}$ & $\begin{array}{c}0.007 * \\
(1.65)\end{array}$ & & $\begin{array}{c}0.008^{*} \\
(1.72)\end{array}$ & & $\begin{array}{l}0.008 \\
(1.59)\end{array}$ & & $\begin{array}{l}0.009 \\
(1.63)\end{array}$ & & $\begin{array}{l}0.006 \\
(0.68)\end{array}$ & & $\begin{array}{l}0.007 \\
(0.75)\end{array}$ & \\
\hline $\begin{array}{l}\text { EMU-country } x \\
\text { post-euro time period } x \\
\text { significant positive euro exposure }\end{array}$ & & $\begin{array}{c}0.015^{* *} \\
(2.39)\end{array}$ & & $\begin{array}{c}0.014 * * \\
(2.38)\end{array}$ & & $\begin{array}{l}0.010 \\
(1.30)\end{array}$ & & $\begin{array}{l}0.010 \\
(1.26)\end{array}$ & & $\begin{array}{c}0.022^{*} \\
(1.95)\end{array}$ & & $\begin{array}{c}0.021^{*} \\
(1.93)\end{array}$ \\
\hline $\begin{array}{l}\text { EMU-country } \mathrm{x} \\
\text { post-euro time period } \mathrm{x} \\
\text { significant negative euro exposure }\end{array}$ & & $\begin{array}{l}-0.003 \\
(-0.37)\end{array}$ & & $\begin{array}{c}0.001 \\
(-0.17)\end{array}$ & & $\begin{array}{l}0.005 \\
(0.56)\end{array}$ & & $\begin{array}{c}0.007 \\
(0.072)\end{array}$ & & $\begin{array}{l}-0.007 \\
(-0.66)\end{array}$ & & $\begin{array}{l}-0.006 \\
(-0.50)\end{array}$ \\
\hline Control variables & Yes & Yes & Yes & Yes & Yes & Yes & Yes & Yes & Yes & Yes & Yes & Yes \\
\hline Year dummies & Yes & Yes & Yes & Yes & Yes & Yes & Yes & Yes & Yes & Yes & Yes & Yes \\
\hline Adjusted $\mathrm{R}^{2}$ & 0.202 & 0.202 & 0.202 & 0.203 & 0.142 & 0.142 & 0.142 & 0.142 & 0.247 & 0.248 & 0.247 & 0.248 \\
\hline Number of firm-year observations & 8,248 & 8,248 & 8,248 & 8,248 & 4,408 & 4,408 & 4,408 & 4,408 & 3,840 & 3,840 & 3,840 & 3,840 \\
\hline
\end{tabular}




\section{Appendix B- Robustness Tests}

\section{Table B1. The introduction of the euro and firm value: Changes in USD exchange rate}

The sample covers the time period 1995-2000 and includes all firms from the EMU-countries (except Luxembourg and Greece) and five non-EMU countries (Denmark, Norway, Sweden, Switzerland and UK) with data available in DataStream for at least the time period 1995-1998. The dependent variable is the log of the Tobin's Q, defined as the sum of the book value of non-equity liabilities and the market value of common equity divided by the book value of total assets. The post-euro time period is defined as years 1998-2000. The EMU-countries classified as weak (i.e., countries with a recent currency crisis) are: Finland, Italy, Ireland, Portugal and Spain. A firm is classified as large if its book value of total assets in 1995 is above the median book value of total assets among sample firms from the same country and year; otherwise it is classified as a small firm. Control variables (log of sales, EBITDA/ total assets, fixed tangible assets / total assets, current year real GDP growth, and current year domestic stock market return) and time dummies are included but not reported. T-statistics based on robust standard errors adjusted for firm dependence within country-years are reported within parentheses. *, **, and ***, denotes significance at the $10 \%, 5 \%$, and $1 \%$ levels, respectively.

\begin{tabular}{|c|c|c|c|c|c|c|}
\hline \multirow[b]{2}{*}{ Explanatory Variable: } & \multicolumn{2}{|c|}{ All firms } & \multicolumn{2}{|c|}{ Large firms } & \multicolumn{2}{|c|}{ Small firms } \\
\hline & $(1)$ & $(2)$ & $(3)$ & $(4)$ & $(5)$ & $(6)$ \\
\hline EMU-country x post-euro time period & $\begin{array}{r}0.058^{*} \\
(1.75)\end{array}$ & & $\begin{array}{l}0.082 * * * \\
(2.70)\end{array}$ & & $\begin{array}{l}0.037 \\
(0.93)\end{array}$ & \\
\hline Strong EMU-country x post-euro time period & & $\begin{array}{l}0.035 \\
(0.98)\end{array}$ & & $\begin{array}{c}0.064 * * \\
(2.01)\end{array}$ & & $\begin{array}{l}0.008 \\
(0.18)\end{array}$ \\
\hline Weak EMU-country x post-euro time period & & $\begin{array}{l}0.134 * * * \\
(3.70)\end{array}$ & & $\begin{array}{c}0.141 * * \\
(4.05)\end{array}$ & & $\begin{array}{l}0.130 * * * \\
(2.84)\end{array}$ \\
\hline $\begin{array}{l}\text { Current year change in the Domestic currency/USD- } \\
\text { exchange rate }\end{array}$ & $\begin{array}{l}0.012 \\
(0.07)\end{array}$ & $\begin{array}{l}0.022 \\
(0.13)\end{array}$ & $\begin{array}{l}0.069 \\
(0.48)\end{array}$ & $\begin{array}{l}0.077 \\
(0.54)\end{array}$ & $\begin{array}{l}-0.049 \\
(-0.25)\end{array}$ & $\begin{array}{l}-0.037 \\
(-0.19)\end{array}$ \\
\hline Control variables & Yes & Yes & Yes & Yes & Yes & Yes \\
\hline Year dummies & Yes & Yes & Yes & Yes & Yes & Yes \\
\hline Adjusted $\mathrm{R}^{2}$ & 0.735 & 0,736 & 0.765 & 0.766 & 0.717 & 0.718 \\
\hline Number of firm-year observations & 10,332 & 10,332 & 5,124 & 5,124 & 5,208 & 5,208 \\
\hline
\end{tabular}


Table B2. The introduction of the euro and firm value: Excluding UK and Germany

The sample covers the time period 1995-2000 and includes all firms from the EMU-countries (except Germany, Luxembourg and Greece) and four non-EMU countries (Denmark, Norway, Sweden, and Switzerland) with data available in Datastream for at least the time period 1995-1998. The dependent variable is the $\log$ of the Tobin's Q, defined as the sum of the book value of non-equity liabilities and the market value of common equity divided by the book value of total assets. The post-euro time period is defined as years 1998-2000. The EMU-countries classified as weak (i.e., countries with a recent currency crisis) are: Finland, Italy, Ireland, Portugal and Spain. A firm is classified as large if its book value of total assets in 1995 is above the median book value of total assets among sample firms from the same country and year; otherwise it is classified as a small firm. T-statistics based on heteroskedasticity-robust standard errors adjusted for firm dependence within country-years are reported within parentheses. *,**, and ***, denotes significance at the $10 \%, 5 \%$, and $1 \%$-levels, respectively.

\begin{tabular}{|c|c|c|c|c|c|c|}
\hline \multirow[b]{2}{*}{ Explanatory Variable: } & \multicolumn{2}{|c|}{ All firms } & \multicolumn{2}{|c|}{ Large firms } & \multicolumn{2}{|c|}{ Small firms } \\
\hline & $(1)$ & $(2)$ & (3) & (4) & $(5)$ & $(6)$ \\
\hline EMU-country x post-euro time period & $\begin{array}{l}0.055^{*} \\
(1.73)\end{array}$ & & $\begin{array}{c}0.056^{*} \\
(1.66)\end{array}$ & & $\begin{array}{l}0.059^{*} \\
(1.68)\end{array}$ & \\
\hline Strong EMU-country x post-euro time period & & $\begin{array}{l}0.023 \\
(0.67)\end{array}$ & & $\begin{array}{l}0.036 \\
(0.97)\end{array}$ & & $\begin{array}{l}0.012 \\
(0.33)\end{array}$ \\
\hline Weak EMU-country x post-euro time period & & $\begin{array}{c}0.105^{* * * *} \\
(3.04)\end{array}$ & & $\begin{array}{c}0.088^{* * *} \\
(2.32)\end{array}$ & & $\begin{array}{c}0.131 * * * \\
(3.28)\end{array}$ \\
\hline Log of sales (in euro) & $\begin{array}{c}-0.031^{*} \\
(-1.58)\end{array}$ & $\begin{array}{l}-0.031 \\
(-1.59)\end{array}$ & $\begin{array}{c}-0.039 * * * \\
(-2.27)\end{array}$ & $\begin{array}{c}-0.040 * * \\
(-2.31)\end{array}$ & $\begin{array}{l}-0.037 \\
(-1.36)\end{array}$ & $\begin{array}{l}-0.035 \\
(-1.31)\end{array}$ \\
\hline EBITDA/ total assets & $\begin{array}{c}0.790 * * * \\
(5.40)\end{array}$ & $\begin{array}{c}0.790 * * * \\
(5.46)\end{array}$ & $\begin{array}{c}1.033 * * * \\
(4.55)\end{array}$ & $\begin{array}{c}1.043 * * * \\
(4.63)\end{array}$ & $\begin{array}{c}0.592 * * * \\
(2.79)\end{array}$ & $\begin{array}{c}0.581 * * * \\
(2.78)\end{array}$ \\
\hline Fixed tangible assets / total assets & $\begin{array}{l}-0.091 \\
(-0.75)\end{array}$ & $\begin{array}{l}-0.089 \\
(-0.75)\end{array}$ & $\begin{array}{l}0.189 \\
(1.56)\end{array}$ & $\begin{array}{l}0.193 \\
(1.60)\end{array}$ & $\begin{array}{c}-0.399 * * * \\
(-2.91)\end{array}$ & $\begin{array}{c}-0.401 * * * \\
(-2.98)\end{array}$ \\
\hline Current year real GDP growth & $\begin{array}{c}4.154 * * * \\
(4.45)\end{array}$ & $\begin{array}{c}4.656^{* * * *} \\
(4.82)\end{array}$ & $\begin{array}{c}3.578 * * * \\
(3.66)\end{array}$ & $\begin{array}{c}3.868 * * * \\
(3.84)\end{array}$ & $\begin{array}{c}4.564 * * * \\
(4.31)\end{array}$ & $\begin{array}{c}5.348 * * * \\
(4.95)\end{array}$ \\
\hline Current year domestic stock market returns & $\begin{array}{l}0.040 \\
(1.63)\end{array}$ & $\begin{array}{l}0.031 \\
(1.13)\end{array}$ & $\begin{array}{l}0.014 \\
(0.51)\end{array}$ & $\begin{array}{l}0.008 \\
(0.25)\end{array}$ & $\begin{array}{c}0.069 * * \\
(2.05)\end{array}$ & $\begin{array}{c}0.056^{*} \\
(1.74)\end{array}$ \\
\hline Year dummies & Yes & Yes & Yes & Yes & Yes & Yes \\
\hline Adjusted $\mathrm{R}^{2}$ & 0.792 & 0.793 & 0.822 & 0.822 & 0.770 & 0.772 \\
\hline Number of firm-year observations & 3,888 & 3,888 & 1,952 & 1,952 & 1,936 & 1,936 \\
\hline
\end{tabular}


Table B3: The introduction of the euro and firm value: Individual year effects

The sample covers the time period 1995-2000 and includes all firms from the EMU-countries (except Luxembourg and Greece) and five non-EMU countries (Denmark, Norway, Sweden, Switzerland, and UK) with data available in Datastream for at least the time period 1995-1998. The dependent variable is the log of the Tobin's Q, defined as the sum of the book value of non-equity liabilities and the market value of common equity divided by the book value of total assets. The post-euro time period is defined as years 1998-2000. A firm is classified as large if its book value of total assets in 1995 is above the median book value of total assets among sample firms from the same country and year; otherwise it is classified as a small firm. Control variables (log of sales, EBITDA/ total assets, fixed tangible assets / total assets, current year real GDP growth, and current year domestic stock market return) and year dummies are included but not reported. T-statistics based on heteroskedasticity-robust standard errors adjusted for firm dependence within country-years are reported within parentheses. *, **, and ***, denotes significance at the $10 \%, 5 \%$, and $1 \%$-levels, respectively.

\begin{tabular}{|c|c|c|c|}
\hline & All firms & Large firms & Small firms \\
\hline Explanatory Variable: & (1) & (2) & (3) \\
\hline EMU-country x 1996 & $\begin{array}{l}-0.020 \\
(-0.47)\end{array}$ & $\begin{array}{l}0.005 \\
(0.13)\end{array}$ & $\begin{array}{l}-0.043 \\
(-0.86)\end{array}$ \\
\hline EMU-country x 1997 & $\begin{array}{l}0.048 \\
(1.04)\end{array}$ & $\begin{array}{l}0.064 \\
(1.54)\end{array}$ & $\begin{array}{l}0.036 \\
(0.65)\end{array}$ \\
\hline EMU-country x 1998 & $\begin{array}{c}0.131 * * * \\
(2.78)\end{array}$ & $\begin{array}{c}0.142 * * * \\
(3.53)\end{array}$ & $\begin{array}{c}0.123^{* *} \\
(2.16)\end{array}$ \\
\hline EMU-country x 1999 & $\begin{array}{l}0.022 \\
(0.44)\end{array}$ & $\begin{array}{l}0.065 \\
(1.39)\end{array}$ & $\begin{array}{l}-0.014 \\
(-0.24)\end{array}$ \\
\hline EMU-country x 2000 & $\begin{array}{l}0.029 \\
(0.59)\end{array}$ & $\begin{array}{c}0.094 * \\
(1.77)\end{array}$ & $\begin{array}{l}-0.029 \\
(-0.50)\end{array}$ \\
\hline Control variables & Yes & Yes & Yes \\
\hline Year dummies & Yes & Yes & Yes \\
\hline Adjusted $\mathrm{R}^{2}$ & 0.730 & 0.755 & 0.715 \\
\hline Number of firm-year observations & 10,332 & 5,124 & 5,208 \\
\hline
\end{tabular}

